\title{
Genotype-specific responses in Atlantic salmon (Salmo salar) subject to dietary fish oil replacement by vegetable oil: a liver transcriptomic analysis
}

\author{
Sofia Morais ${ }^{1 *}$, Jarunan Pratoomyot ${ }^{1}$, John B Taggart ${ }^{1}$, James E Bron ${ }^{1}$, Derrick R Guy ${ }^{2}$, J Gordon Bell ${ }^{1}$ and
} Douglas R Tocher $^{1}$

\begin{abstract}
Background: Expansion of aquaculture is seriously limited by reductions in fish oil (FO) supply for aquafeeds. Terrestrial alternatives such as vegetable oils (VO) have been investigated and recently a strategy combining genetic selection with changes in diet formulations has been proposed to meet growing demands for aquaculture products. This study investigates the influence of genotype on transcriptomic responses to sustainable feeds in Atlantic salmon.

Results: A microarray analysis was performed to investigate the liver transcriptome of two family groups selected according to their estimated breeding values (EBVs) for flesh lipid content, 'Lean' or 'Fat', fed diets containing either FO or a VO blend. Diet principally affected metabolism genes, mainly of lipid and carbohydrate, followed by immune response genes. Genotype had a much lower impact on metabolism-related genes and affected mostly signalling pathways. Replacement of dietary FO by VO caused an up-regulation of long-chain polyunsaturated fatty acid biosynthesis, but there was a clear genotype effect as fatty acyl elongase (elovl2) was only up-regulated and desaturases ( $\Delta 5 \mathrm{fad}$ and $\Delta 6 \mathrm{fad}$ ) showed a higher magnitude of response in Lean fish, which was reflected in liver fatty acid composition. Fatty acid synthase (FAS) was also up-regulated by VO and the effect was independent of genotype. Genetic background of the fish clearly affected regulation of lipid metabolism, as PPAR $\alpha$ and PPAR $\beta$ were downregulated by the VO diet only in Lean fish, while in Fat salmon SREBP-1 expression was up-regulated by VO. In addition, all three genes had a lower expression in the Lean family group than in the Fat, when fed VO. Differences in muscle adiposity between family groups may have been caused by higher levels of hepatic fatty acid and glycerophospholipid synthesis in the Fat fish, as indicated by the expression of FAS, 1-acyl-sn-glycerol-3-phosphate acyltransferase and lipid phosphate phosphohydrolase 2.

Conclusions: This study has identified metabolic pathways and key regulators that may respond differently to alternative plant-based feeds depending on genotype. Further studies are required but data suggest that it will be possible to identify families better adapted to alternative diet formulations that might be appropriate for future genetic selection programmes.
\end{abstract}

\section{Background}

Fish are highly nutritious components of the human diet. In addition to providing high quality and easily digested protein, vitamins and minerals, they are particularly important in being the main source of essential n-3 longchain polyunsaturated fatty acids (LC-PUFA). The beneficial effects of these fatty acids, such as eicosapentaenoic

\footnotetext{
* Correspondence: sofia.morais@stir.ac.uk

${ }^{1}$ Institute of Aquaculture, University of Stirling, Stirling FK9 4LA, UK

Full list of author information is available at the end of the article
}

acid (EPA) and docosahexaenoic acid (DHA), include prevention of a range of cardiovascular and inflammatory diseases, and neurological disorders [1]. With catches from commercial fisheries stagnating since 2001, aquaculture is supplying an increasing proportion of fish for human consumption, estimated at around $50 \%$ of total supply in 2008 [2]. However, the expansion of aquaculture and the demands it makes upon resources provide many challenges, leading to questions concerning the sustainability of this activity. In particular, marine and salmonid aquaculture relies heavily on fish meal (FM)
C Biomed Central

() 2011 Morais et al; licensee BioMed Central Ltd. This is an Open Access article distributed under the terms of the Creative Commons Attribution License (http://creativecommons.org/licenses/by/2.0), which permits unrestricted use, distribution, and reproduction in any medium, provided the original work is properly cited. 
and fish oil (FO), obtained from wild fishery stocks, for the production of fish feeds and around $88.5 \%$ of the total global production of FO is currently used by aquaculture [3]. The increasing scarcity of FO supplies will seriously limit aquaculture growth, and the future of this activity therefore strongly depends on reducing its reliance on FO by seeking to replace them with alternative, largely terrestrial, oils. Vegetable oils (VO) represent a potentially critical resource in this respect. However, $\mathrm{VO}$ lack the n-3 LC-PUFA which are abundant in FO, and farming fish on diets containing a high proportion of $\mathrm{VO}$ results in lower levels of these omega- 3 fatty acids in flesh, compromising their health-promoting effects to the human consumer [4].

The use of selective breeding programs to enhance traits of commercial importance is becoming increasingly more common in aquaculture [5]. Combining genetic selection with changes in commercial feed formulations (i.e., higher levels of inclusion of $\mathrm{VO}$ ) may be a viable strategy to meet worldwide demand for farmed fish without compromising animal welfare or nutritional value. Recently we showed that deposition and/or retention in flesh of dietary n-3 LC-PUFA, EPA and DHA, is a highly heritable trait in salmon [6], prompting further interest in exploring genotype-nutrient interactions. Other recent work has investigated potential interactions between genetic selection for body fatness and dietary lipid level in rainbow trout $[7,8]$, and the effects of FM and/or FO replacement on the liver transcriptome of both rainbow trout and Atlantic salmon [9-11]. However, there are few data on the interaction between genotype and dietary fatty acid composition. In this respect, microarrays have great potential for application as hypothesis-generating tools. The objective of the present study was to investigate nutrient-genotype interactions in two groups of Atlantic salmon families, Lean and Fat, fed diets where FO was completely replaced by a VO blend. The knowledge gained concerning how this substitution affects hepatic metabolism and, furthermore, how these effects may depend on the genetic background of the fish, not only informs our understanding of lipid metabolism more generally but is also highly relevant to the strategy of genetic selection for families better adapted to alternative and more sustainable feed formulations in the future. A previous study has already focused on hepatic cholesterol and lipoprotein metabolism [12], which was shown to present a significant diet $\times$ genotype interaction, while here we will present more broadly the effects of the factors 'diet' and 'genotype'.

\section{Results}

\section{Microarray results}

Two-way ANOVA of the cDNA microarray dataset returned a high number of features showing evidence of differential expression for each factor - 713 for diet and 788 for genotype - and hence a more detailed analysis was restricted to the top 100 most significant hits for each factor, which were then categorised according to function (excluding 33-35\% non-annotated features) (Figure 1). The functional category most affected by diet was that of metabolism (mainly lipid and carbohydrate metabolism), while immune response and intracellular trafficking were also affected. Within lipid metabolism, the affected genes are involved in PUFA, fatty acid and cholesterol biosynthesis (fatty acyl desaturases $-\Delta 5 \mathrm{fad}$ and $\Delta 6$ fad, fatty acid synthase - FAS, squalene monooxygenase and possibly cytochrome $\mathrm{P} 450$ reductase), glycerophospholipid metabolism (phospholipase D3) and acylglycerol homeostasis (angiopoietin-like 3). Some genes related to carbohydrate metabolism, implicated in glycolysis, glutamine/fructose 6-phosphate and glycerol3 -phosphate metabolism, such as alpha-enolase, glutamine-fructose-6-phosphate transaminase 1(GFPT1) and glycerol kinase, respectively, were also identified as being significantly affected by diet. Genotype had a lower impact on metabolism-related genes (primarily

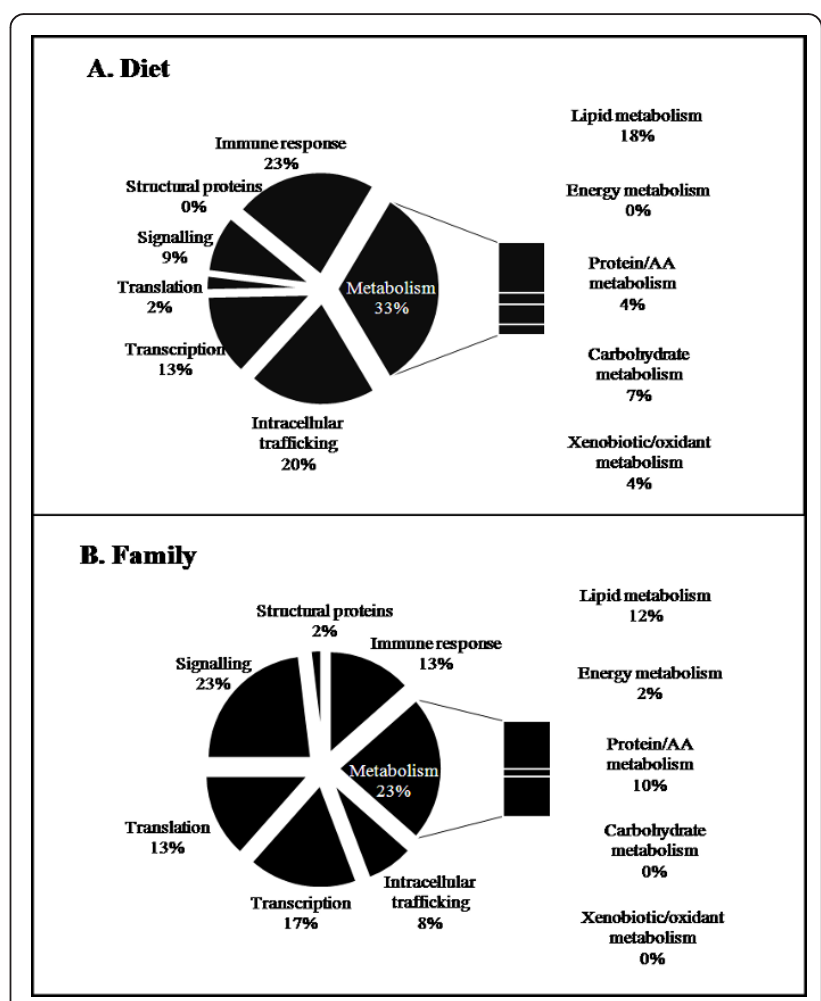

Figure 1 Functional categories of genes differentially expressed in Atlantic salmon liver. The top 100 most significant clones (twoway ANOVA analysis; $p<0.05)$ which were differentially expressed between the two diets (A) and family groups (B) were categorized according to biological function. Non-annotated clones, those representing the same gene or with a miscellaneous function (Tables 2 and 3) are not represented. 
lipid and protein metabolism) and affected mostly genes involved in signalling. Regarding lipid metabolism, primary roles of affected genes are in glycerophospholipid metabolism (N-acylethanolamine-hydrolyzing acid amidase precursor, lipid phosphate phosphohydrolase 2 LPP2 and 1-acyl-sn-glycerol-3-phosphate acyltransferase - AGPAT), fatty acid transport (intestinal fatty acid binding protein) and lipoprotein metabolism (apolipoprotein B - ApoB and endothelial lipase - EL). In addition, both factors had an effect on a relatively high number of transcription-related genes. Detailed lists of the top 100 most significant genes for diet and genotype, organised by biological function and including the normalised expression ratio between treatments, are shown in Tables 1 and 2, respectively. Gene Ontology enrichment analysis, which enables the identification of GO terms significantly enriched in the input entity list when compared to the whole array dataset, was performed for both factors, providing evidence for which biological processes may be particularly altered in the experimental conditions being compared. For diet, seven significant GO terms, all interrelated, were identified: oxidoreductase activity, stearoyl-CoA 9-desaturase activity, unsaturated fatty acid biosynthetic and metabolic processes, very long chain fatty acid (VLCFA) biosynthetic and metabolic processes. This is explained by the high number of $\Delta 5$ fad and $\Delta 6$ fad features that were significantly altered when dietary FO was replaced by VO (Table 1). In contrast, no GO terms were significantly enriched in the genotype list.

\section{RT-qPCR}

Quantification of gene expression by RT-qPCR was performed to partially validate the microarray results and to examine particular genes of interest in detail. The latter included several fatty acyl desaturase and elongase genes involved in the LC-PUFA biosynthesis pathway that were identified by GO analysis as being significantly affected by diet, as well as peroxisome proliferator-activated receptors (PPAR) and sterol regulatory element binding protein 1 (SREBP-1), which have important roles in regulating the expression of multiple lipid metabolism genes (Table 3). In spite of the generally low fold changes, a good correspondence in terms of expression ratios or in the direction of change (up- or down-regulation), was obtained between the microarray and RT-qPCR results for most quantified genes, including $\Delta 5$ fad and $\Delta 6 \mathrm{fad}$, FAS and heme oxygenase 1 (HOX) for the factor diet, and ApoB, LPP2 and AGPAT for the factor genotype (Tables 1, 2, 3). However, comparison of the microarray and RT-qPCR expression results show an inverse change in expression for GFPT1 and glutathione S-transferase A (GST) in response to diet, the latter only in the Fat group, and of EL between family groups, although only when feeding on FO (where the fold-change in the microarray was negligible). Nonetheless, a perfect match was not expected given that RT-qPCR primers were obtained either from published work (e.g., GST) or, when available, designed on well characterized sequences such as GenBank reference sequences or clusters on the gene index database for Atlantic salmon (ASGI), which do not necessarily match exactly the clone on the array. In fact, in the case of EL there is evidence that the microarray probe has high similarity with multiple EST's and hence is likely to have resulted in cross-hybridisation [12], while the reference sequence for GFPT1 and the clone in the microarray are only $93 \%$ identical in the aligned region.

In terms of regulation of gene expression by the factor diet, the qPCR results confirmed the significant up-regulation of $\Delta 5$ fad and $\Delta 6$ fad in fish fed VO, with a higher fold change being measured for $\Delta 6 \mathrm{fad}$. In addition, the expression ratio was higher in the Lean family group than in Fat fish, as had also been indicated in the microarray analysis. Of the elongase genes, only elovl 2 was significantly up-regulated by the VO diet, but just in the Lean family group. Furthermore, quantification of PPAR genes revealed that only PPAR $\alpha$ was down-regulated significantly when salmon were fed the VO diet, but only in the Lean family group. On the other hand, expression of SREBP-1 was only significantly affected in Fat fish, being up-regulated in fish fed the VO diet. Other genes which were significantly and consistently regulated were FAS and EL (both up-regulated when $\mathrm{VO}$ replaced FO in the diet), while GST, HOX and AGPAT only showed significant regulation in Fat fish. Finally, comparison between the two family groups showed a significantly lower expression of $\Delta 5 \mathrm{fad}, \Delta 6 \mathrm{fad}$, PPAR $\alpha$, PPAR $\beta$, SREBP- 1 and GST in the Lean group but only when fish were fed FO, in the case of fads, or when fed the VO diet, in the case of PPARs, SREBP-1 and GST. In addition, FAS was also significantly down-regulated in the Lean group, independent of diet.

\section{Liver fatty acid composition}

Fatty acid analysis of liver showed significant differences in all fatty acid classes related mostly to diet but also to genotype (except for total n-3 PUFA and total PUFA) (Table 4). The percentage of total n-6 PUFA (reflecting mainly 18:2n-6) was significantly increased when VO replaced FO in the diet. Levels of total n-3 PUFA were, on the other hand, significantly higher in the FO treatments independent of genotype. For EPA and DHA there was a significant diet $\times$ genotype interaction, resulting from the fact that, when comparing Fat and Lean fish, higher levels of these LC-PUFA were found in the Fat family group when fed the FO diet but the inverse was observed when the same fish were fed the VO diet. 
Table 1 Liver transcripts corresponding to the top 100 most significant features exhibiting differential expression between diets

\begin{tabular}{|c|c|c|c|c|}
\hline \multirow[t]{2}{*}{ Accession or probe number } & \multirow[t]{2}{*}{ Gene } & \multicolumn{2}{|c|}{ VO/FO } & \multirow[t]{2}{*}{ ANOVA p-value } \\
\hline & & Lean & Fat & \\
\hline
\end{tabular}

Metabolism

Lipid metabolism

$$
\begin{gathered}
\text { can_D6D_S1B04 } \\
\text { can_D6D_S1B03 } \\
\text { can_D5D_S1B01 } \\
\text { can_D6O_S1B06 } \\
\text { CK887422 } \\
\text { EG647320 } \\
\text { CK876943 } \\
\text { can_D5D_S1B02 } \\
\text { CK894344 } \\
\text { EG647463 } \\
\text { liv_Irr_01F07 } \\
\text { can_D5O_S1B05 } \\
\text { CK879648 }
\end{gathered}
$$

Protein and amino acid metabolism CK893821 CK884400

Carbohydrate metabolism

$$
\begin{gathered}
\text { int_OSs_T4F08 } \\
\text { liv_Irr_01A06 } \\
\text { CO470771 }
\end{gathered}
$$

Xenobiotic and oxidant metabolism

$$
\begin{aligned}
& \text { AJ425332 } \\
& \text { EG355339 }
\end{aligned}
$$

Transport/intracellular trafficking

CK886667

CN181143

DW588711

CK894482

CK887866

CO470399

EG647422

EG648286

AM083913

Regulation of transcription

$$
\begin{aligned}
& \text { CK894063 } \\
& \text { CK890154 } \\
& \text { EG648112 } \\
& \text { CK885196 } \\
& \text { CK890573 } \\
& \text { CK883722 }
\end{aligned}
$$

Translation

AM402452

Signalling/Signal transduction

CK886572

CK892148

ova_opk_09K06

CK873849
Delta-6 fatty acyl desaturase

Delta-6 fatty acyl desaturase

Delta-5 fatty acyl desaturase

Delta-6 fatty acyl desaturase

Delta- 6 fatty acyl desaturase

Delta-6 fatty acyl desaturase

Fatty acid synthase

Delta-5 fatty acyl desaturase

Phospholipase D3

Cytochrome $\mathrm{P} 450$ reductase

Angiopoietin-like 3

Delta-6 fatty acyl desaturase

Squalene monooxygenase

Sequestosome 1or ubiquitin-binding protein P62

Kynureninase (L-kynurenine hydrolase)

Alpha-enolase putative

Glutamine-fructose-6-phosphate transaminase 1

Glycerol kinase

2.8

1.9

$<0.0001$

$2.1 \quad 1.4$

$<0.0001$

$2.3 \quad 1.5$

$<0.0001$

$2.0 \quad 1.4$

$<0.0001$

$2.0 \quad 1.8$

$<0.0001$

0.0001

0.0002

$1.4 \quad 1.6$

0.0003

$2.1 \quad 1.2$

$\begin{array}{ll}-1.1-1.2 \\ -1.4 & -1.1\end{array}$

0.0006

$\begin{array}{lll}-1.4 & -1.1 & 0.0017\end{array}$

$1.2 \quad 1.4$

0.0020

$1.5 \quad 1.2$

0.0045

$1.9 \quad 1.1$

0.0058

$\begin{array}{lll}-1.3 & -1.1 & 0.0022\end{array}$

$\begin{array}{lll}1.3 & 1.2 & 0.0065\end{array}$

$\begin{array}{lll}-1.2 & -1.0 & 0.0007\end{array}$

$\begin{array}{lll}1.2 & 1.8 & 0.0032\end{array}$

$\begin{array}{lll}1.1 & 1.1 & 0.0062\end{array}$

Thioredoxin domain-containing protein 8

Glutathione S-transferase A

$\begin{array}{lll}-1.3 & -1.3 & 0.0024\end{array}$

$\begin{array}{lll}-1.4 & -1.4 & 0.0036\end{array}$

$\mathrm{Na} / \mathrm{K}$ ATPase

Coatomer subunit alpha

Synaptic vesicle glycoprotein $2 B$

Taurine transporter

$1.5 \quad 1.1 \quad<0.0001$

$\begin{array}{lll}1.2 & 1.4 & 0.0004\end{array}$

$\begin{array}{ccc}1.1 & 1.1 & 0.0004\end{array}$

$\begin{array}{lll}-1.3 & -1.3 & 0.0019\end{array}$

$\begin{array}{cccc}\text { ABC-type branched-chain amino acid transport systems ATPase component } & 1.2 & 1.1 & 0.0022 \\ \text { Sodium/potassium-transporting } & -1.2 & -1.2 & 0.0044\end{array}$

$$
\text { Transferrin }
$$

$\begin{array}{lll}-1.2 & -1.1 & 0.0047\end{array}$

ATP-binding cassette sub-family B member 10, mitochondrial

Chromatin modifying protein $2 a$

$\begin{array}{cc}1.2 & 1.3\end{array}$

0.0055

$\begin{array}{lll}-1.3 & -1.2 & 0.0068\end{array}$

$\begin{array}{lll}-1.5 & -1.3 & 0.0003\end{array}$

$\begin{array}{lll}1.5 & 1.1 & 0.0043\end{array}$

$\begin{array}{lll}1.1 & 1.3 & 0.0046\end{array}$

$\begin{array}{lll}1.2 & 1.2 & 0.0052\end{array}$

$\begin{array}{lll}1.2 & 1.2 & 0.0053\end{array}$

$\begin{array}{lll}1.1 & 1.3 \quad 0.0067\end{array}$

Y-box binding protein

Phenylalanyl-tRNA synthetase, alpha subunit

0.0022

GSK-3-binding protein

Growth factor receptor-bound protein 7

Phosphoinositide 3-protein kinase

Receptor-type tyrosine-protein phosphatase beta precursor
1.4

$\begin{array}{lll}1.9 & 1.0 & 0.0002\end{array}$

$\begin{array}{lll}-1.5 & -1.1 & 0.0028\end{array}$

$\begin{array}{lll}-1.1 & -1.3 & 0.0031\end{array}$

$\begin{array}{lll}-1.1 & -1.1 \quad 0.0036\end{array}$ 
Table 1 Liver transcripts corresponding to the top 100 most significant features exhibiting differential expression between diets (Continued)

\begin{tabular}{|c|c|c|c|c|}
\hline DW590775 & Myozenin-1 & 1.6 & 1.5 & 0.0055 \\
\hline \multicolumn{5}{|l|}{ Immune response } \\
\hline EG647383 & Human leukocyte antigen (HLA) class II histocompatibility & 1.1 & 1.2 & 0.0008 \\
\hline AM402762 & Complement component C8 alpha chain & 1.3 & 1.7 & 0.0018 \\
\hline EG649410 & D-dopachrome tautomerase & 1.4 & 1.1 & 0.0019 \\
\hline AJ425750 & Non-histone chromosomal protein $\mathrm{H} 6$ & 1.1 & 1.3 & 0.0024 \\
\hline CK884265 & Ganglioside GM2 activator & 1.3 & 1.1 & 0.0030 \\
\hline AM402841 & Complement component C8 alpha chain & 1.5 & 2.1 & 0.0032 \\
\hline CK886548 & T cell receptor (TCR)-alpha/delta locus & -1.2 & -1.0 & 0.0041 \\
\hline spl_sts_18A08 & Leukotriene B4 receptor 1 putative & -1.4 & -1.1 & 0.0047 \\
\hline CK880083 & Interleukin-15 precursor & 1.1 & 1.3 & 0.0067 \\
\hline AJ425732 & CD97 antigen isoform 2 & 1.2 & 1.1 & 0.0066 \\
\hline \multicolumn{5}{|c|}{ Miscellaneous and unknown function } \\
\hline CK897269 & Biotinidase precursor & 1.3 & 1.7 & 0.0002 \\
\hline AM402518 & Biotinidase & 1.4 & 1.9 & 0.0006 \\
\hline CK894173 & EFHD2 (EF hand domain containing2) & 1.2 & 1.1 & 0.0007 \\
\hline kid_cki_A1E04 & S100-A1 calcium binding & 1.4 & 1.1 & 0.0009 \\
\hline CO469646 & beta B3-crystallin & -1.1 & -1.0 & 0.0012 \\
\hline CO469710 & Transmembrane protein 30A & -1.1 & -1.2 & 0.0019 \\
\hline AJ425502 & Heme oxygenase 1 & -2.7 & -1.7 & 0.0024 \\
\hline CK885237 & EF-hand domain-containing protein D2 & 1.1 & 1.1 & 0.0026 \\
\hline AJ425502 & Heme oxygenase 1 & -2.6 & -1.4 & 0.0037 \\
\hline DW588567 & S100 calcium binding protein beta subunit & 1.1 & 1.1 & 0.0042 \\
\hline CK897725 & Type-1 growth hormone & 1.1 & 1.1 & 0.0053 \\
\hline BM414485 & Apoptosis-inducing factor mitochondrion-associated inducer & 1.5 & 1.4 & 0.0054 \\
\hline BM414504 & Syndecan 2 & -1.2 & -1.1 & 0.0061 \\
\hline B|468143 & Anaphase-promoting complex subunit CDC26 & -1.3 & -1.3 & $0.0064 / p>$ \\
\hline CK885116 & 17-beta hydroxysteroid dehydrogenase 13 & -1.1 & -1.4 & 0.0065 \\
\hline
\end{tabular}

Annotated features (65\% of all clones) are arranged by categories of biological function and, within these, by decreasing significance (assessed by two-way ANOVA). Also indicated are the GenBank accession numbers for each clone (or, when not available, the probe number is given instead) and the expression ratio between fish fed VO and those fed FO, for each genotype (Lean and Fat).

Table 2 Liver transcripts corresponding to the top 100 most significant features exhibiting differential expression between family groups

\begin{tabular}{|c|c|c|c|c|}
\hline \multirow[t]{2}{*}{ Accession or probe number } & \multirow[t]{2}{*}{ Gene } & \multicolumn{2}{|c|}{ Lean/Fat } & \multirow[t]{2}{*}{ ANOVA p-va } \\
\hline & & FO & Vo & \\
\hline \multicolumn{5}{|l|}{ Metabolism } \\
\hline \multicolumn{5}{|l|}{ Lipid metabolism } \\
\hline CK889835 & $\mathrm{N}$-acylethanolamine-hydrolyzing acid amidase precursor & -1.4 & -1.2 & 0.0001 \\
\hline can_Apo_S1A12 & Apolipoprotein B & -1.4 & -1.1 & 0.0014 \\
\hline BM414066 & Endothelial lipase precursor & -1.1 & -1.6 & 0.0015 \\
\hline CK898924 & Lipid phosphate phosphohydrolase 2 & -1.2 & -1.2 & 0.0017 \\
\hline AJ425826 & Intestinal fatty acid binding protein & 1.1 & 1.2 & 0.0032 \\
\hline CO470953 & 1-acyl-sn-glycerol-3-phosphate acyltransferase & -1.1 & -1.3 & 0.0040 \\
\hline \multicolumn{5}{|c|}{ Energy metabolism/generation of precursor metabolites } \\
\hline EG649459 & NADH dehydrogenase (ubiquinone) 1 beta subcomplex & 1.2 & 1.2 & 0.0009 \\
\hline \multicolumn{5}{|l|}{ Protein and amino acid metabolism } \\
\hline CK900470 & 265 protease regulatory subunit 7 & -1.1 & -1.2 & 0.0020 \\
\hline mus_mfo_15B08 & Proteasome subunit alpha type-1 & 1.2 & 1.1 & 0.0021 \\
\hline EG648604 & Serine protease-like protein & 1.0 & 1.4 & 0.0023 \\
\hline
\end{tabular}


Table 2 Liver transcripts corresponding to the top 100 most significant features exhibiting differential expression between family groups (Continued)

\begin{tabular}{|c|c|c|c|c|}
\hline CO470297 & Transmembrane protease, serine 2 & -1.2 & -1.1 & 0.0032 \\
\hline DW592216 & Ubiquitin carboxyl-terminal hydrolase 5 & -1.1 & -1.1 & 0.0040 \\
\hline \multicolumn{5}{|c|}{ Transport/intracellular trafficking } \\
\hline CK886667 & $\mathrm{Na} / \mathrm{K}$ ATPase & 1.1 & 1.6 & $<0.0001$ \\
\hline CK884193 & Polycystin-2 (Polycystic kidney disease 2 protein homolog) & 1.1 & 1.2 & 0.0002 \\
\hline CK890974 & Mitochondrial solute carrier family 25 member 25 & -1.2 & -2.2 & 0.0002 \\
\hline CK896189 & Mitochondrial solute carrier family 25 member 25 & -1.3 & -2.3 & 0.0002 \\
\hline CK880187 & ATP-binding cassette sub-family B member 8 , mitochondrial & -1.3 & -1.1 & 0.0011 \\
\hline \multicolumn{5}{|l|}{ Regulation of transcription } \\
\hline CK881770 & Hematopoietically-expressed homeobox protein & -1.1 & -1.6 & 0.0001 \\
\hline CK888834 & BTEB transcription factor & -1.4 & -1.5 & 0.0002 \\
\hline CK895950 & Transcription factor CP2-like & -1.2 & -1.6 & 0.0010 \\
\hline CK884953 & Nuclear transcription factor $Y$ subunit beta & -1.2 & -1.1 & 0.0015 \\
\hline CK888548 & Rev protein - Human immunodeficiency virus 1 & -1.5 & -1.0 & 0.0019 \\
\hline CK883410 & Retinoic acid receptor gamma (nuclear receptor) & -1.1 & -1.1 & 0.0020 \\
\hline int_rpk_78B12 & Sp3 transcription factor & -1.1 & -1.4 & 0.0035 \\
\hline CK876044 & Homeobox protein HoxB13 & -1.2 & -1.2 & 0.0041 \\
\hline DW589427 & Cullin-associated and neddylation-dissociated 1 (CAND1) & 1.4 & 1.1 & 0.0044 \\
\hline \multicolumn{5}{|l|}{ Translation } \\
\hline AJ424434 & Ribosome production factor 1 & 1.1 & 1.2 & 0.0002 \\
\hline gil_oss_G6P11 & $40 S$ ribosomal protein $\$ 23$ & 1.3 & 1.3 & 0.0008 \\
\hline EG648403 & $60 S$ ribosomal protein $\mathrm{L} 7 \mathrm{a}$ & 1.2 & 1.2 & 0.0013 \\
\hline CK893177 & $40 S$ ribosomal protein $\$ 26$ & 1.1 & 1.2 & 0.0013 \\
\hline DW591137 & $40 S$ ribosomal protein S3a & -1.2 & -1.1 & 0.0024 \\
\hline EG647811 & 605 ribosomal protein $L 7$ & 1.1 & 1.1 & 0.0026 \\
\hline EG648956 & Eukaryotic translation initiation factor $1 \mathrm{~A}$ & 1.1 & 1.1 & 0.0033 \\
\hline AJ424851 & $40 S$ ribosomal protein $\$ 18$ & 1.2 & 1.2 & 0.0034 \\
\hline \multicolumn{5}{|c|}{ Signalling/Signal transduction } \\
\hline CK884714 & 14-3-3 protein epsilon & 1.1 & 1.1 & 0.0003 \\
\hline EG648400 & Guanine nucleotide binding protein (G protein) & -1.2 & -1.2 & 0.0004 \\
\hline CK888542 & Insulin-like growth factor binding protein 1 & -1.2 & -2.5 & 0.0008 \\
\hline CK886572 & GSK-3-binding protein putative & -1.1 & 1.8 & 0.0009 \\
\hline CK877143 & Calpain-1 & -1.1 & -1.4 & 0.0010 \\
\hline EG648399 & PTC7 protein phosphatase homolog & -1.2 & -1.1 & 0.0016 \\
\hline EG648333 & Stathmin & 1.1 & 1.2 & 0.0018 \\
\hline CK898969 & G-protein coupled receptor 37 & -1.1 & -1.1 & 0.0019 \\
\hline DW589782 & Amyloid beta (A4) precursor-like protein & 1.1 & 1.2 & 0.0034 \\
\hline CK898590 & Mitogen-activated protein kinase kinase 4 & -1.0 & -1.2 & 0.0035 \\
\hline CK897997 & Calpastatin & -1.1 & -1.1 & 0.0039 \\
\hline AJ424385 & Protein tyrosine phosphatase, receptor-type, zeta1 & -1.1 & -1.2 & 0.0041 \\
\hline \multicolumn{5}{|l|}{ Structural proteins } \\
\hline AJ425204 & Tropomyosin-1 alpha (muscle contraction) & -1.1 & -1.2 & 0.0031 \\
\hline \multicolumn{5}{|l|}{ Immune response } \\
\hline CK886548 & T cell receptor (TCR)-alpha/delta locus & -1.1 & -1.2 & 0.0005 \\
\hline CK894741 & Complement factor D (adapsin) & -1.1 & -1.2 & 0.0007 \\
\hline AM042439 & Major histocompatibility complex (MHC) class I antigene & -1.3 & -1.4 & 0.0014 \\
\hline kid_cki_A1G02 & Interferon-inducible protein & -1.2 & -1.4 & 0.0015 \\
\hline CO471904 & Major histocompatability complex (MHCl) & -1.1 & -1.2 & 0.0019 \\
\hline CK894557 & Major histocompatability complex (MHCl) & -1.2 & -1.1 & 0.0023 \\
\hline AM042249 & Major histocompatability complex (MHCl) & -1.1 & -1.2 & 0.0025 \\
\hline bra_opk_01B08 & Scavenger receptor cysteine-rich gene & -1.3 & -1.6 & 0.0029 \\
\hline
\end{tabular}


Table 2 Liver transcripts corresponding to the top 100 most significant features exhibiting differential expression between family groups (Continued)

\begin{tabular}{|c|c|c|c|c|}
\hline CO469739 & T-cell receptor(TCR)-alpha/delta locus & -1.1 & -1.1 & 0.0030 \\
\hline AJ424124 & Major histocompatibility complex (MHC class I) & -1.2 & -1.1 & 0.0037 \\
\hline hrt_opk_07E23 & Interferon alpha 1-like & -1.1 & -1.1 & 0.0041 \\
\hline \multicolumn{5}{|c|}{ Miscellaneous and unknown function } \\
\hline CK898014 & Protein fuzzy homolog & -1.1 & -1.2 & 0.0002 \\
\hline kid_cki_A2A05 & Cyclin B2 & -1.3 & -1.4 & 0.0006 \\
\hline EG647643 & Purine nucleoside phosphorylase & -1.1 & -2.0 & 0.0010 \\
\hline liv_Irr_07B04 & Nuclear protein 1 & -1.1 & -2.1 & 0.0028 \\
\hline AM402622 & Non-POU domain containing, octamer-binding & -1.7 & -1.4 & 0.0029 \\
\hline EG648147 & Adhesion-regulating molecule 1 & -1.2 & -1.1 & 0.0037 \\
\hline BM414485 & Apoptosis-inducing factor mitochondrion-associated inducer & 1.4 & 1.5 & 0.0038 \\
\hline DW589496 & Cyclin-dependent kinase inhibitor & -1.2 & -1.3 & 0.0044 \\
\hline
\end{tabular}

Annotated features (67\% of all clones) are arranged by categories of biological function and, within these, by decreasing significance (assessed by two-way ANOVA). Also indicated are the GenBank accession numbers for each clone (or, when not available, the probe number is given instead) and the expression ratio between Lean and Fat fish fed either FO or VO.

\section{Discussion}

In the present study we analysed the effects of diets containing high levels of plant proteins and with complete replacement of FO by VO on the liver transcriptome of Atlantic salmon, which is the primary metabolic organ of fish, as well as the influence of genotype on these responses. Here we focus on the separate effects of diet and genotype given that interactions, indicating pathways that were differentially affected by diet depending on the genetic background of the fish, were discussed in detail previously [12].

A common methodological difficulty in this type of nutritional experiment is that effects are typically quite subtle although physiological and metabolic pathways can be impacted by even small fold changes in gene expression. This has been demonstrated by several studies

Table 3 Relative expression of genes assayed by RT-qPCR in liver of Atlantic salmon

\begin{tabular}{|c|c|c|c|c|c|c|c|c|}
\hline \multirow[b]{3}{*}{ Genes } & \multicolumn{4}{|c|}{ VO/FO } & \multicolumn{4}{|c|}{ Lean/Fat } \\
\hline & \multicolumn{2}{|c|}{ Lean } & \multicolumn{2}{|c|}{ Fat } & \multicolumn{2}{|c|}{ FO } & \multicolumn{2}{|c|}{ VO } \\
\hline & Ratio & p-value & Ratio & p-value & Ratio & p-value & Ratio & p-value \\
\hline$\Delta 5 \mathrm{fad}$ & 3.95 & 0.001 & 2.04 & 0.002 & -2.33 & 0.009 & -1.20 & 0.317 \\
\hline$\Delta 6$ fad_a & 8.27 & 0.000 & 4.52 & 0.004 & -1.85 & 0.049 & -1.02 & 0.942 \\
\hline elovl5a & 1.18 & 0.505 & -1.03 & 0.817 & -1.18 & 0.420 & 1.03 & 0.908 \\
\hline elovl5b & 1.57 & 0.184 & 1.05 & 0.758 & -1.25 & 0.471 & 1.19 & 0.416 \\
\hline elovl2 & 2.35 & 0.025 & -1.04 & 0.841 & -1.56 & 0.098 & 1.58 & 0.112 \\
\hline FAS & 1.76 & 0.005 & 2.11 & 0.003 & -1.72 & 0.001 & -2.04 & 0.011 \\
\hline PPAR $\alpha$ & -2.22 & 0.000 & 1.10 & 0.643 & -1.16 & 0.358 & -2.86 & 0.001 \\
\hline PPAR $\beta$ & -1.92 & 0.161 & 1.56 & 0.169 & 1.24 & 0.659 & -2.44 & 0.002 \\
\hline PPAR $\gamma$ & -1.10 & 0.828 & -1.67 & 0.251 & -2.00 & 0.214 & -1.32 & 0.229 \\
\hline SREBP-1 & -1.16 & 0.761 & 3.32 & 0.004 & 1.82 & 0.332 & -2.13 & 0.022 \\
\hline GST & -1.18 & 0.412 & 1.40 & 0.010 & 1.29 & 0.210 & -1.28 & 0.028 \\
\hline HOX & -2.69 & 0.132 & -1.82 & 0.013 & 1.83 & 0.271 & 1.24 & 0.120 \\
\hline GFPT1 & -1.33 & 0.244 & -1.65 & 0.090 & -1.18 & 0.619 & 1.05 & 0.783 \\
\hline ApoB & 1.40 & 0.443 & 1.84 & 0.152 & -1.15 & 0.791 & -1.52 & 0.076 \\
\hline EL & 3.52 & 0.034 & 8.57 & 0.002 & 1.38 & 0.494 & -1.75 & 0.115 \\
\hline LPP2 & -1.33 & 0.506 & -1.31 & 0.606 & -1.22 & 0.754 & -1.25 & 0.516 \\
\hline AGPAT & 1.40 & 0.375 & 1.42 & 0.041 & -1.05 & 0.906 & -1.07 & 0.574 \\
\hline
\end{tabular}

Values are normalised (by cofilin-2) gene expression ratios between fish fed VO in relation to FO for each family group or of Lean fish in relation to the Fat group when fed either one of the diets. Values in bold are significantly different, at $\mathrm{p}<0.05$ (REST 2008).

fad: fatty acyl desaturase ( $\Delta 5$ and $\Delta 6$ ); elovl: elongase (three different transcripts); FAS: Fatty acid synthase; PPARs; peroxisome proliferator-activated receptors (three isoforms); SREBP-1: Sterol regulatory element binding protein-1; GST: glutathione S-transferase A; HOX: heme oxygenase 1; GFPT1: glutamine-fructose-6phosphate transaminase 1; ApoB: apolipoprotein B; EL: endothelial lipase; LPP2: lipid phosphate phosphohydrolase 2; AGPAT: 1-acyl-sn-glycerol-3-phosphate acyltransferase. 
Table 4 Liver fatty acid composition (percentage of total fatty acids) of Atlantic salmon Lean and Fat family groups fed diets containing either FO or VO

\begin{tabular}{|c|c|c|c|c|c|c|c|}
\hline \multirow[t]{2}{*}{ Parameters } & \multicolumn{2}{|c|}{ FO } & \multicolumn{2}{|c|}{ VO } & \multicolumn{3}{|c|}{ ANOVA } \\
\hline & Fat & Lean & Fat & Lean & Diet & Genotype & Diet $\times$ Gen \\
\hline \multicolumn{8}{|l|}{ Fatty acid } \\
\hline Total saturated & $25.8 \pm 0.8$ & $22.1 \pm 1.5$ & $19.1 \pm 1.0$ & $18.3 \pm 1.0$ & $<0.0001$ & $<0.0001$ & 0.0044 \\
\hline Total monoenes & $23.8 \pm 1.3$ & $31.1 \pm 2.5$ & $40.8 \pm 3.3$ & $39.0 \pm 2.5$ & $<0.0001$ & 0.0141 & 0.0002 \\
\hline $18: 2 n-6$ & $2.9 \pm 0.1$ & $3.0 \pm 0.3$ & $10.1 \pm 0.2$ & $10.4 \pm 0.2$ & $<0.0001$ & 0.0317 & ns \\
\hline $18: 3 n-6$ & $0.1 \pm 0.1$ & $0.1 \pm 0.1$ & $0.1 \pm 0.1$ & $0.1 \pm 0.0$ & ns & ns & ns \\
\hline $20: 2 n-6$ & $0.5 \pm 0.0$ & $0.7 \pm 0.0$ & $1.6 \pm 0.2$ & $1.9 \pm 0.1$ & $<0.0001$ & $<0.0001$ & ns \\
\hline $20: 3 n-6$ & $0.4 \pm 0.0$ & $0.4 \pm 0.0$ & $1.3 \pm 0.1$ & $1.4 \pm 0.1$ & $<0.0001$ & ns & ns \\
\hline $20: 4 n-6$ & $2.2 \pm 0.2$ & $1.9 \pm 0.2$ & $1.2 \pm 0.1$ & $1.4 \pm 0.1$ & $<0.0001$ & ns & 0.0009 \\
\hline $22: 5 n-6$ & $0.2 \pm 0.0$ & $0.2 \pm 0.1$ & $0.1 \pm 0.0$ & $0.1 \pm 0.0$ & $<0.0001$ & ns & ns \\
\hline Total n-6 PUFA & $6.3 \pm 0.3$ & $6.3 \pm 0.4$ & $14.4 \pm 0.3$ & $15.3 \pm 0.3$ & $<0.0001$ & 0.0031 & 0.0031 \\
\hline $18: 3 n-3$ & $1.0 \pm 0.0$ & $1.1 \pm 0.2$ & $4.3 \pm 0.2$ & $4.7 \pm 0.2$ & $<0.0001$ & 0.0021 & 0.0466 \\
\hline $18: 4 n-3$ & $0.4 \pm 0.1$ & $0.4 \pm 0.1$ & $0.3 \pm 0.0$ & $0.3 \pm 0.1$ & 0.0104 & ns & ns \\
\hline $20: 3 n-3$ & $0.2 \pm 0.0$ & $0.3 \pm 0.0$ & $0.7 \pm 0.1$ & $0.7 \pm 0.3$ & $<0.0001$ & ns & ns \\
\hline $20: 4 n-3$ & $1.6 \pm 0.1$ & $2.3 \pm 0.3$ & $1.1 \pm 0.1$ & $1.3 \pm 0.1$ & $<0.0001$ & $<0.0001$ & 0.0021 \\
\hline $20: 5 n-3$ & $8.6 \pm 0.3$ & $8.2 \pm 0.4$ & $4.7 \pm 0.4$ & $5.2 \pm 0.4$ & $<0.0001$ & ns & 0.0085 \\
\hline $22: 5 n-3$ & $3.6 \pm 0.2$ & $4.4 \pm 0.3$ & $1.9 \pm 0.2$ & $2.1 \pm 0.1$ & $<0.0001$ & $<0.0001$ & 0.0025 \\
\hline $22: 6 n-3$ & $28.6 \pm 1.0$ & $23.7 \pm 1.9$ & $12.6 \pm 1.5$ & $13.1 \pm 1.1$ & $<0.0001$ & 0.0011 & 0.0002 \\
\hline Total n-3 PUFA & $44.1 \pm 1.1$ & $40.5 \pm 1.5$ & $25.7 \pm 2.4$ & $27.4 \pm 1.4$ & $<0.0001$ & ns & 0.0009 \\
\hline Total PUFA & $50.4 \pm 1.2$ & $46.8 \pm 1.5$ & $40.2 \pm 2.6$ & $42.8 \pm 1.6$ & $<0.0001$ & ns & 0.0004 \\
\hline
\end{tabular}

Results are means \pm SD $(n=6)$ and p-values of two-way ANOVA are presented for factors 'diet', 'genotype' and interaction between both factors. ns, not significantly different $(p>0.05)$.

$[7,9,11]$ and by previously reported data from the present study showing that low fold changes in gene expression were associated with biochemical differences in tissue lipid class and apolipoprotein composition [12]. Furthermore, low fold changes observed in this study were generally corroborated by RT-qPCR, even if the low expression ratios meant that differences were not always significant. It should also be noted that a total match between the microarray and the RT-qPCR results is not expected due to the approach taken to design RT-qPCR primers on better annotated reference sequences rather than on less well characterized microarray clones. In view of the whole genome duplication event that occurred in salmonid fishes [13], transcriptomic and gene expression studies are often more challenging due to the presence of duplicated and highly similar genes whose transcripts might be differentially regulated, as observed previously for lipoprotein lipase [12]. Therefore, collectively, and in conjunction with previous studies, data obtained in the present microarray study enabled identification of pathways that may be differentially affected by both dietary oil composition and genetic background related to flesh adiposity.

\section{Effects of diet on lipid metabolism}

Within the list of genes affected by diet, those involved in fatty acyl desaturation were prominent, leading to the identification, through GO enrichment analysis, of several terms related to LC-PUFA biosynthetic and metabolic processes. The up-regulation of $\Delta 5 \mathrm{fad}$ and $\Delta 6 \mathrm{fad}$ in both family groups when dietary FO was replaced by VO was confirmed by RT-qPCR. Several studies have previously demonstrated up-regulation of genes involved in LC-PUFA biosynthesis in salmon when FO is replaced by VO $[10,14,15]$. RT-qPCR also confirmed previous work showing that elovl2 is responsive to dietary n-3 LCPUFA levels [15], being the only elongase whose expression was up-regulated when FO was replaced by VO. However, a significant effect was only observed in the Lean family group. In addition, both microarray and RTqPCR analyses indicated that the up-regulation of $\Delta 5 \mathrm{fad}$ and $\Delta 6$ fad showed a considerably higher fold-change in the Lean fish, due mainly to lower basal expression of fads in Lean salmon, compared to Fat, when fed FO. These results indicate that the activity of this biosynthetic pathway may be dependent on the genetics of the fish, with different family groups showing differences in the magnitude of response. The liver fatty acid composition revealed that differences in EPA and DHA levels between fish fed either diet were smaller in the Lean fish, due to higher n-3 LC-PUFA in fish fed VO and lower n-3 LCPUFA in fish fed FO, compared to the equivalent treatments in the Fat group. In addition, intermediates in the biosynthetic pathway, such as 20:4n-3 and 22:5n-3, tended to be present at higher levels in the Lean family 
group, suggesting that differences observed in the levels of mRNA of LC-PUFA biosynthesis genes, which have been shown to correlate with the enzymatic activity of this pathway in salmon $[16,17]$, were reflected in biochemical composition.

Another lipid metabolism gene significantly affected by diet was FAS, which was up-regulated in both family groups when fed VO. A well demonstrated effect of dietary FO supplementation in mammals is hypotriglyceridemia, resulting from a coordinated effect of n-3 LC-PUFA in suppressing hepatic lipogenesis and enhancing fatty acid oxidation in liver and muscle [18]. Furthermore, this gene also appears to be regulated at a pre-translational level and hence changes in FAS transcription are likely to result in important effects in terms of enzyme activity [19]. Similar mechanisms are believed to operate in fish but, although reduced hepatic lipogenic activity modulated by LC-PUFA has been demonstrated in vitro [20], a direct relationship with dietary FO and VO has not always been clear in vivo [21,22]. The regulation of FAS in response to FO replacement by $\mathrm{VO}$ did not show an interaction with the flesh leanness/fatness phenotype in this study, as might have been expected. This was because genotype also had a significant effect, with the Lean group having lower levels of FAS expression than the Fat fish, with a similar fold-change in both diets.

Regulation of lipid metabolism is complex and controlled by several transcription factors and nuclear receptors, including PPARs and SREBPs. SREBP-1c is a major regulator of lipogenesis in mammals [18]. Here we measured the expression of SREBP-1 as there is no evidence for the existence of alternatively spliced isoforms in salmon, and primers corresponded to an identical region in mammalian SREBP-1a and SREBP-1c [23]. Our results agree with Minghetti et al. [23], who showed SREBP-1 was increased by cholesterol and decreased by EPA and DHA supplementation in a salmon cell line, denoting a similar nutritional regulation to mammals [18]. However, there was a clear genetic effect as expression of SREBP-1 was 3-fold higher in Fat salmon fed VO, containing lower EPA, DHA and cholesterol, than in fish fed FO, whereas no regulation was observed in the Lean group.

PPARs have been less studied in fish than in mammals but present evidence suggests PPAR $\alpha$ and PPAR $\beta$ have similar ligands and functions to their mammalian homologues, while PPAR $\gamma$ may present some functional differences $[24,25]$. LC-PUFA are well recognised enhancers of PPAR $\alpha$ activity in fish, and while the response of PPAR $\beta$ to LC-PUFA might be variable between fish species, an enhancement of activity in sea bass, plaice and sea bream [24-26] and of expression in Atlantic salmon [27] has been observed. In addition, and unlike rodents, PPAR $\alpha$ and PPAR $\beta$ have a similar pattern of expression in response to fasting and feeding in sea bream liver, indicating that they may be regulated similarly [25]. In the present study, PPAR $\alpha$ was down-regulated when VO replaced FO but only in the Lean family group and, although not statistically significant, PPAR $\beta$ showed a similar trend, suggesting similar transcriptional regulation of these nuclear receptors by dietary fatty acid composition. These results thus indicate that the genetic background of the fish might affect PPAR transcriptional responses to LC-PUFA. In contrast, no nutritional regulation was observed for PPAR $\gamma$ transcription in liver, in accordance with previous studies in fish, including salmon, and its predominant role in adipocytes [24,28].

The hypotriglyceridemic effects of n-3 LC-PUFA in mammals involve activation of PPAR $\alpha$, leading to up-regulation of $\beta$-oxidation genes (including carnitine palmitoyltransferase I - CPT1 and acyl-CoA oxidase - ACO) and suppression of SREBP-1c transcription that down-regulates lipogenic enzymes $[29,30]$. As previously reported, FAS expression was up-regulated in both family groups fed the VO diet but neither CPT1 nor ACO expression, was affected [12]. As elovl2 expression was only altered in the Lean fish and both $\Delta 5$ fad and $\Delta 6$ fad showed greater up-regulation in Lean salmon fed VO, we may speculate that PPAR $\alpha$ (and potentially also PPAR $\beta$ ) expression may be involved in down-regulation of LC-PUFA biosynthesis. Paradoxically, fatty acyl desaturases are regulated by both SREBPs and PPARs in mammals [31]. In addition, PPAR $\alpha$ agonists regulate the transcriptional activity of elongases in rat, although only elovl5 and not elovl2 [32]. However, in mammals, PPAR $\alpha$ ligands induce the transcription of elongases and desaturases while we observed an up-regulation of elovl 2 and a stronger stimulation of $\Delta 5 \mathrm{fad}$ and $\Delta 6$ fad transcription when PPAR $\alpha$ expression was lower. In the rat and human $\Delta 6$ fad gene promoters, both PUFA and PPAR $\alpha$ response regions have been identified which suppress and induce, respectively, $\Delta 6$ fad expression [33]. The molecular mechanisms of transcriptional regulation of these genes are complex and will require further investigation in salmon [34]. In contrast, target genes of SREBP-1 remain elusive and, although it may regulate FAS expression [23], this was only observed in Fat fish whereas, in the Lean group, another mechanism is required to explain upregulation of FAS in VO-fed fish as expression of SREBP1 was unaffected. Nonetheless, the action of SREBP-1 is under the regulation of liver $\mathrm{X}$ receptor (LXR) and these complex pathways have only recently started to be investigated in fish [23].

Another gene affected by diet was squalene epoxidase (SQLE), which was up-regulated by VO but only markedly in the Lean family group. This enzyme catalyses the first oxygenation step in sterol biosynthesis, a pathway identified earlier as presenting a diet $\times$ genotype interaction [12]. In contrast, cytochrome $\mathrm{P} 450$ reductase (CPR) was down-regulated in salmon fed VO, particularly in 
Lean fish. This enzyme has multiple roles as the electron donor for several oxygenase enzymes, such as cytochrome P450 (involved in drug and xenobiotic metabolism, and sterol and bile acid synthesis), HOX and cytochrome b5 (which supports both sterol and LCPUFA biosynthesis pathways). In addition, it has key roles in the biosynthesis of several signalling factors and the regulation of oxidative response genes [reviewed by [35]]. CPR is transcriptionally regulated by PPAR $\alpha$ in mouse and, given the comparable PPAR $\alpha$ and CPR expression in Lean salmon fed $\mathrm{VO}$, similar regulation likely occurs in salmon. However, changes in CPR expression can be related to several processes that were affected by FO replacement. Thus, CPR expression could be linked to changes in both cholesterol and LC-PUFA biosynthesis, both more marked in Lean fish, although this is unlikely because $\mathrm{VO}$ induced up-regulation of these pathways. A more likely association is with cell oxidant metabolism, also suggested by the microarray results as being possibly down-regulated in VO-fed fish. In particular, down-regulation of HOX in salmon fed VO, more marked for Lean fish correlating with CPR expression, might be an indication of this.

\section{Effect of diet on carbohydrate and intermediate metabolism}

Within the metabolism genes that were identified by the microarray analysis as being significantly affected by dietary oil substitution, a few relate to carbohydrate metabolism, particularly glucose and intermediary metabolism. Given that similar effects were observed in previous salmonid studies, and that a few signal transduction genes present in the list of diet significant effects are also potentially implicated in these pathways, these results warrant further discussion, even if the observed fold changes were low. An association between lipid and carbohydrate metabolism in salmon is not surprising given that the pathways of lipogenesis, lipolysis, glycolysis, gluconeogenesis and pentose phosphate shunt are all interrelated in the regulation of body energy homeostasis. In mammals, the role of LC-PUFA as "fuel partitioners" involves both directing fatty acids away from anabolic and towards catabolic routes as well as enhancing glucose flux to glycogen, mediated by effects on SREBP-1 and transcription factors that regulate key genes of lipid metabolism and glycolysis [30]. Similar mechanisms may operate in fish but differences are likely given that carnivorous fish like salmon have low capacity to use carbohydrate and appear to show features of glucose intolerance $[36,37]$. Nonetheless, dietary $n-3 / n-6$ ratio has been shown to influence mRNA levels of the glucose transporter GLUT4 in Atlantic salmon muscle, with some reflection in plasma glucose [38]. In addition to a decreased hexokinase and phosphoenolpyruvate carboxykinase expression, complete replacement of FM and FO by vegetable alternatives in rainbow trout resulted in a slightly increased expression of glycerol kinase, as observed here [11]. This enzyme is at the intersection of lipid-carbohydrate metabolism and over-expression of this gene in human muscle and rat hepatoma cells resulted in higher TAG synthesis and up-regulation of the pentose phosphate pathway providing reducing power for lipogenesis [39]. Panserat et al. [11] hypothesised that the up-regulation of glycerol kinase may be related to higher lipid biosynthesis in liver when trout were fed plant-based diets. Similarly, our results, associated with the observed changes in FAS mRNA when VO replaced FO, suggest a possible relationship with lipogenesis. Also possibly related with this was the upregulation of two different biotinidase clones with the potential to increase availability of substrates for FAS and/or gluconeogenesis in VO-fed fish. This gene, besides being involved in the regulation of gene expression, including genes of glucose metabolism, codes for an enzyme that recycles biotin, which is a co-factor for several carboxylases responsible for production of substrates for lipogenesis and gluconeogenesis [40].

Another gene affected by diet was alpha-enolase, which was slightly down regulated in Lean fish fed VO. A similar effect was observed in liver of salmon fed rapeseed oil in comparison to FO [9]. This glycolytic enzyme participates in the conversion of glucose to pyruvate, a key intermediate at the intersection of multiple metabolic pathways, including lipogenesis. Thus, this might result in lower levels of pyruvate for conversion to acetyl-CoA in VO-fed fish. This result does not necessarily conflict with an increase in lipogenesis given that, in fish, carbon skeletons for de novo fatty acid production are mainly derived from amino acid catabolism rather than from carbohydrates, whose main contribution towards lipogenesis is to supply NADPH via the pentose-phosphate pathway [37].

Finally, a few signalling genes that were significantly affected by diet might also have an effect on glucose metabolism, assuming that similar cascades exist in fish. One of these is phosphoinositide 3-protein kinase (PI3K), which mediates insulin's effects on glucose, lipid and protein metabolism, and that was significantly down regulated in VO-fed fish. Among other roles, it regulates glucose cellular uptake in mammals, recruiting GLUT4 transporters to the cell surface [41]. In addition, it is found upstream of a signal transduction cascade regulating glycogen synthesis through glycogen synthase, by inactivating glycogen synthase kinase-3 (GSK3) [41,42]. In our study, expression of GSK3-binding protein (GBP) was significantly increased in VO-fed Lean fish. GBP is a protein that blocks GSK3, which in turn inactivates glycogen synthase [43]. Hence, it is possible that the oil composition of the diet might also affect glucose metabolism and glycogen storage. 
Effect of diet on oxidative stress and immune response Increased oxidative stress associated with the consumption of FO has been typically reported in fish and mammals $[27,44,45]$. Accordingly, genes related to oxidant metabolism were found in the significant list for diet. A thioredoxin domain-containing protein, possessing an antioxidant role [46], and GST, which detoxifies peroxidised lipids and xenobiotics [47], were down-regulated in salmon fed VO, consistent with the higher auto-oxidative potential of LC-PUFA in FO. However, quantification of GST by RT-qPCR was not consistent with the microarray result, although the possibility exists that different GST genes with differential regulation exist in salmon and this requires clarification. In addition, the observed down-regulation of HOX in VO-fed fish, validated by RT-qPCR, might be related to a decrease in oxidative stress in these fish. This enzyme catalyses the degradation of heme and can be induced by oxidative stress [48] and may be increased during pro-inflammatory states, being thought to increase resistance to oxidative injury and ameliorate inflammation [49]. The n-3 LC-PUFA in FO have important anti-inflammatory actions in mammals [50], which does not correlate with the expression of HOX and its putative role in inflammation in this case. Inflammation is an important mechanism in immune defence but, in fish, the demonstrated effects of LC-PUFA on immune and inflammatory mechanisms have been inconsistent [45]. However, a recent study has clearly shown an effect of dietary oil composition on the progression of a myxosporean parasite infection in Gilthead sea bream, with fish fed the VO diet showing higher signs of the disease and faster course of infection in comparison with those on a FO diet [51]. On the other hand, the synthesis of pro-inflammatory eicosanoids was increased in the intestine of salmon fed vegetable-based diets in response to acute stress [52]. In the present study immune response was the second highest category of genes affected by diet, after metabolism. Whether this is due to the potential anti-inflammatory role of dietary FO or whether VO diets can have detrimental health effects is not clear as the fold-changes were subtle, as expected in unchallenged animals. Nonetheless, the majority of genes related to processes of both innate and adaptive immunity were up-regulated in fish fed VO. Only $\mathrm{T}$-cell and leukotriene $\mathrm{B}_{4}\left(\mathrm{LTB}_{4}\right)$ receptors, that are reduced after antigen and $\mathrm{LTB}_{4}$ exposure, respectively, and, in the case of $\mathrm{LTB}_{4}$ receptor, increased after EPA administration [53-55], were down-regulated in salmon fed VO.

\section{Differences in gene expression between Lean and Fat genotypes}

Muscle adiposity is a trait of great importance in animal production, aquaculture included, and hence physiological changes induced by genetic selection for this phenotype have been examined in various animals, including rainbow trout $[7,8]$. In the present study the main differences between family groups were associated with signal transduction pathways, followed by metabolism. Only a small number of lipid metabolism genes varied in relation to muscle adiposity, as reported previously in rainbow trout, where the main differences were related to lipogenesis and mitochondrial oxidative metabolism $[7,8]$. In our study glycerophospholipid metabolism may have been down-regulated in the Lean family group through AGPAT and LPP2, two enzymes acting consecutively on de novo TAG and phospholipid biosynthesis $[56,57]$. Quantification of AGPAT and LPP2 expression by RT-qPCR confirmed this down-regulation but foldchanges were too subtle to be significant. AGPAT converts lysophosphatidic acid into phosphatidic acid (PA), while LPP2 then catalyzes the conversion of PA to diacylglycerol. All these molecules can function as second messengers and are involved in the regulation of multiple signalling pathways. Therefore, down-regulation of this pathway in the Lean group has the potential to lower lipid biosynthesis, at least partly explaining the flesh lipid phenotype, but may also alter levels of lipid signalling molecules. On the other hand, differences in muscle adiposity might also be caused by higher hepatic "de novo" fatty acid synthesis in the Fat family group, as indicated by the expression of FAS. In a previous study, no differences were found in the expression of ACO and CPT1, which suggested that the phenotypes could not be explained by differences in $\beta$-oxidation [12]. By contrast, in rainbow trout Fat and Lean families, $\beta$-oxidation and mitochondrial oxidative metabolism, but not lipogenesis, were affected by genetic selection [7], although another study using the same trout lines suggested differences related to lipogenesis rather than fatty acid oxidation [8]. Thus, both metabolic processes are likely involved and discrepancies in the data are likely due to lack of methodological sensitivity to detect the small fold-changes that are possibly characteristic of these biological processes and typical in this type of experiment.

PPAR $\alpha$, PPAR $\beta$ and SREBP-1 were also regulated in response to genotype, being down-regulated in Lean fish, but only when fed the VO diet. In cobia, Rachycentron canadum, a negative correlation was found between PPAR $\alpha$ mRNA levels in liver and body lipid deposition [58]. Furthermore, PPAR $\beta$ appears to play a similar role in fish to that in mammals, as a ubiquitous regulator of fat burning and with a role in energy mobilisation during early development $[24,25]$. Therefore, both PPAR $\alpha$ and PPAR $\beta$ might have a role in the control of adipogenesis in fish and it may be the case that, similarly to chickens [59], Fat salmon might have higher lipid turnover than their Lean counterparts when fed a diet that predisposes for hepatic fat deposition, even though the end result is 
higher lipid accumulation in liver [60]. To explain this, Collin et al. [59] suggested that a fat chicken family is better "equipped" to deal with higher circulating levels of TAG when fed a high fat diet, compared to lean chicken. On the other hand, we observed a direct relationship between SREBP-1 and FAS expression in the Fat family group in response to diet, as well as in VO-fed fish in response to genotype. It thus appears that SREBP-1 may be partly responsible for higher lipogenesis in Fat fish, compared to Lean, when fed VO.

\section{Conclusions}

This study has enabled the identification of metabolic pathways and key regulators that may respond differently to more sustainable diets, in which FO is replaced by VO, depending on genotype, thus confirming the potential of microarrays as hypothesis-generating tools, even in these nutritional studies where changes in gene expression are quite subtle. Collectively, and in conjunction with previous studies, the data indicate that dietary lipid composition may potentially affect glucose, glycogen storage and intermediary metabolism, in addition to lipogenesis, supporting a role for LC-PUFA in "fuel partitioning" in fish as well as in mammals. Therefore, more integrative studies investigating the effects of dietary $\mathrm{VO}$ on energy homeostasis are required. However, important genotype-related differences may also exist in the regulation of metabolism. In terms of lipid metabolism, expression of LC-PUFA and lipid biosynthesis genes, as well as of key regulator transcriptional factors, was differentially affected by diet depending on the genetic background of the fish. Although further studies are required, the present data indicate that it will be possible to identify families better adapted to alternative diet formulations that might be appropriate for future genetic selection programmes.

\section{Methods}

\section{Feeding trial and sampling}

A dietary trial was conducted using two genetically characterised and contrasting groups of farmed Atlantic salmon post-smolts, comprising full-sib families selected from the Landcatch Natural Selection Ltd (LNS) breeding program (Argyll, Scotland). The choice of the two family groups was based on estimated breeding values (EBVs) of the parents for high or low flesh adiposity, assessed by Torry Fatmeter (Distell Industries, West Lothian, UK), a trait that was found to have a heritability ranging from 0.17 to 0.39 in this dataset. The two groups were created from four unrelated full-sib families; two families from the extreme lower end of the EBV distribution for flesh lipid content ('Lean') and two families from the extreme upper end of the distribution ('Fat'). The average EBV for the lipid content of the two Fat families was 2.00 percentage units higher than that of the two selected Lean families, representing a standardised selection differential of 2.33 standard deviations. Assessment of the flesh and viscera lipid content at the end of the feeding trial confirmed differences in adiposity between the two genotypes, in spite of an interaction with diet being also found [12].

Two thousand fish of each group were stocked into eight $12 \times 5 \mathrm{~m}^{3}$ net pens at the Ardnish Fish Trials Unit (Marine Harvest Scotland, Lochailort, Highland; 500 fish pen $\left.^{-1}\right)$. Duplicate pens from each group of fish were fed one of two experimental diets (Skretting ARC, Stavanger, Norway) containing $32-25 \%$ fish meal, $40-45 \%$ plant meals and $27.5-30 \%$ oil supplied either as northern fish oil (FO) or as a vegetable oil (VO) blend comprising rapeseed, palm and Camelina oils in a ratio of 5:3:2 [12]. Diets were formulated to fully satisfy the nutritional requirements of salmonid fish [61] and contained similar levels of PUFA (around 31\%) but different n-3 and n-6 PUFA contents, $25.3 \%$ and $4.6 \%$ in the FO diet and $13.4 \%$ and $17.1 \%$ in the VO diet, respectively. Further details including full diet formulations, proximate and fatty acid compositions of the feeds can be found in Bell et al. [60].

After 55 weeks on the experimental diets 25 fish were sampled per pen. The fish were killed by a blow to the head following anaesthesia using MS222, 24 h after the last meal. Samples of liver were immediately frozen on dry ice and stored at $-70^{\circ} \mathrm{C}$ for molecular and fatty acid analyses.

\section{RNA extraction and purification}

Liver tissue $(0.2 \mathrm{~g})$ from six individuals per experimental group was rapidly homogenised in $2 \mathrm{~mL}$ of TRI Reagent (Ambion, Applied Biosystems, Warrington, U.K.) using an Ultra-Turrax tissue disrupter (Fisher Scientific, Loughborough, U.K.) and stored at $-70^{\circ} \mathrm{C}$. Total RNA was later isolated, following manufacturer's instructions, and RNA quality (integrity and purity) and quantity was assessed by gel electrophoresis and spectrophotometry (NanoDrop ND-1000, Thermo Scientific, Wilmington, U.S.A.). One hundred micrograms of total RNA from each individual sample was further cleaned by mini spin-column purification (RNeasy Mini Kit, Qiagen, Crawley, UK), and then requantified and quality assessed as above.

\section{Microarray hybridizations and image analysis}

The TRAITS/SGP (v.2.1) salmon 17 k cDNA microarray, described in detail by Taggart et al. [10], was used in this experiment (ArrayExpress accession: A-MEXP1930). A dual-label experimental design was employed for the microarray hybridisations. Each experimental sample was competitively hybridised against a common pooled-reference sample, which comprised equal 
amounts of all samples used in the study. This design permits valid statistical comparisons across all treatments to be made. The entire experiment comprised 24 hybridisations -2 genotypes (Lean/Fat) $\times 2$ diets $(\mathrm{FO} /$ $\mathrm{VO}) \times 6$ biological replicates.

An indirect labelling methodology was employed in preparing the microarray targets. Antisense amplified RNA (aRNA) was produced from $500 \mathrm{ng}$ of purified total RNA per sample using the Amino Allyl MessageAmpTM II aRNA Amplification Kit (Ambion, Applied Biosystems), as per manufacturer's instructions, followed by $\mathrm{Cy} 3$ or $\mathrm{Cy} 5$ fluor incorporation mediated by a dyecoupling reaction, as previously described in detail [12]. Experimental samples and the pooled reference sample (batch reaction) were labelled with $\mathrm{Cy} 3$ and $\mathrm{Cy} 5$ dye suspension stocks (PA23001 or PA25001, GE HealthCare, Little Chalfont, UK), respectively. Unincorporated dye was removed by column purification (Illustra AutoSeq G-50 spin columns; GE Healthcare). Dye incorporation and aRNA yield were quantified by spectrophotometry (NanoDrop ND-1000) and further quality controlled by separating $0.4 \mu \mathrm{L}$ of the sample through a thin mini-agarose gel and visualising products on a fluorescence scanner (Typhoon Trio, GE Healthcare).

Microarray hybridisations were performed in a Lucidea semi-automated system (GE Healthcare), without a prehybridisation step. For hybridisation of each array, each labelled biological replicate and corresponding pooled reference ( 40 pmol each dye, c. 150 ng aRNA) were combined and added to the hybridisation solution, comprising $185 \mu \mathrm{L}$ 0.7X UltraHyb buffer (Ambion), $20 \mu \mathrm{L}$ poly (A) at $10 \mathrm{mg} / \mathrm{mL}$ (Sigma-Aldrich, Dorset, UK), $10 \mu \mathrm{L}$ herring sperm at c. $10 \mathrm{mg} / \mathrm{mL}$ (Sigma-Aldrich) and $10 \mu \mathrm{L}$ ultra pure BSA at $10 \mathrm{mg} / \mathrm{mL}$ (Sigma-Aldrich), as detailed previously [12]. Two post-hybridisation automatic washes followed by six manual washes to a final stringency of $0.1 \times$ SSC (EasyDipTM Slide staining system; Canemco Inc., Quebec, Canada) were performed before scanning.

Scanning was performed at $10 \mu \mathrm{m}$ resolution using an Axon GenePix 4200AL Scanner (MDS Analytical Technologies, Wokingham, Berkshire, U.K.) with laser power constant $(80 \%)$ and "auto PMT" enabled to adjust PMT for each channel such that less than $0.1 \%$ of features were saturated and that the mean intensity ratio of the $\mathrm{Cy} 3$ and Cy5 signals was close to one. BlueFuse software (BlueGnome, Cambridge, U.K.) was then used to identify features and extract fluorescence intensity values from the resultant TIF images. Following a manual spot removal procedure and fusion of duplicate spot data (BlueFuse proprietary algorithm), the resulting fluorescence intensity data and quality annotations for the 17,102 gene features, were exported into the GeneSpring GX version 10.0.2 analysis platform (Agilent Technologies, Wokingham, Berkshire, U.K.) after undergoing a block Lowess normalisation.
Data transformation and quality filtering were then performed and all control features were excluded from subsequent analyses [12]. This returned a list of 14,772 genes eligible for statistical analysis. Experimental annotation complied fully with minimum information about a microarray experiment (MIAME) guidelines [62]. The experimental hybridisations and further methodological details are archived on the EBI ArrayExpress database (http:// www.ebi.ac.uk/arrayexpress/) under accession number E-TABM-1089.

\section{RT-qPCR}

Expression of selected genes was determined by reverse transcription quantitative real time PCR (RT-qPCR). Details on the target qPCR primer sequences are given in Table 5. In addition, amplification of three potential reference genes - cofilin-2, elongation factor- $1 \alpha(e l f-1 \alpha)$ and $\beta$ actin - was performed. However, only cofilin-2 expression proved to be sufficiently stable across treatments for normalisation of the results. Cofilin-2 had been established in a previous salmon cDNA microarray study as a suitable reference gene on the basis of constant expression between FO and VO based feeds over a wide range of time points ('unidentified liver EST', [10]).

For RT-qPCR, $1 \mu \mathrm{g}$ of column-purified total RNA per sample was reverse transcribed into cDNA using the VersoTM cDNA kit (ABgene, Surrey, U.K.), following manufacturer's instructions, using a mixture of random hexamers $(400 \mathrm{ng} / \mu \mathrm{L})$ and anchored oligo-dT (500 ng/ $\mu \mathrm{L})$ at $3: 1(\mathrm{v} / \mathrm{v})$. Negative controls (containing no enzyme) were performed to check for genomic DNA contamination. A similar amount of cDNA was pooled from all samples and the remaining cDNA was then diluted 20-fold with water. RT-qPCR analysis used relative quantification with the amplification efficiency of the primer pairs being assessed by serial dilutions of the cDNA pool. qPCR amplifications were carried out in duplicate (Quantica, Techne, Cambridge, U.K.) in a final volume of $20 \mu \mathrm{L}$ containing either $5 \mu \mathrm{L}$ or $2 \mu \mathrm{L}$ (for the reference genes and HOX) diluted (1/20) cDNA, $0.5 \mu \mathrm{M}$ of each primer and $10 \mu \mathrm{L}$ AbsoluteTM QPCR SYBR ${ }^{\circledR}$ Green mix (ABgene). Amplifications were carried out with a systematic negative control (NTC-non template control). The qPCR profiles contained an initial activation step at $95^{\circ} \mathrm{C}$ for $15 \mathrm{~min}$, followed by 30 to 40 cycles (depending on target): $15 \mathrm{~s}$ at $95^{\circ} \mathrm{C}, 15 \mathrm{~s}$ at the specific primer pair annealing temperature (Ta; Table 5) and 15 $\mathrm{s}$ at $72^{\circ} \mathrm{C}$. After the amplification phase, a melt curve of $0.5^{\circ} \mathrm{C}$ increments from $75^{\circ} \mathrm{C}$ to $90^{\circ} \mathrm{C}$ was performed, enabling confirmation of the amplification of a single product in each reaction. RT-qPCR product sizes were checked by agarose gel electrophoresis and the identity of amplicons of newly designed primers (FAS, GFPT1, HOX, LPP2 and AGPAT) was confirmed by sequencing. 
Table 5 Primers used for RT-qPCR analyses

\begin{tabular}{|c|c|c|c|c|c|c|}
\hline Transcript & Primer sequence $\left(5^{\prime}-3^{\prime}\right)$ & Fragment & $\mathrm{Ta}$ & Efficiency & Accession No. & Source \\
\hline \multirow[t]{2}{*}{$\Delta 5 \mathrm{fad}$} & GTGAATGGGGATCCATAGCA & $192 \mathrm{bp}$ & $56^{\circ} \mathrm{C}$ & 0.995 & AF478472 ${ }^{1}$ & {$[66]$} \\
\hline & AAACGAACGGACAACCAGA & & & & & \\
\hline \multirow[t]{2}{*}{$\Delta 6 f a d \_a$} & CCCCAGACGTTTGTGTCAG & $181 \mathrm{bp}$ & $56^{\circ} \mathrm{C}$ & 0.944 & AY458652 ${ }^{1}$ & {$[66]$} \\
\hline & CCTGGATTGTTGCTITGGAT & & & & & \\
\hline \multirow[t]{2}{*}{ elovl5a } & ACAAGACAGGAATCTCTITCAGATTAA & $137 \mathrm{bp}$ & $60^{\circ} \mathrm{C}$ & 0.925 & AY170327 ${ }^{1}$ & {$[15]$} \\
\hline & TCTGGGGTTACTGTGCTATAGTGTAC & & & & & \\
\hline \multirow[t]{2}{*}{ elovl5b } & ACAAAAAGCCATGTTTATCTGAAAGA & $141 \mathrm{bp}$ & $60^{\circ} \mathrm{C}$ & 0.940 & DW546112 ${ }^{1}$ & {$[15]$} \\
\hline & CACAGCCCCAGAGACCCACTT & & & & & \\
\hline \multirow[t]{2}{*}{ elovl2 } & CGGGTACAAAATGTGCTGGT & $145 \mathrm{bp}$ & $60^{\circ} \mathrm{C}$ & 0.960 & TC91192 2 & {$[15]$} \\
\hline & TCTGTTTGCCGATAGCCATT & & & & & \\
\hline \multirow[t]{2}{*}{ FAS } & GTGCCCACTGAATACCATCC & $212 \mathrm{bp}$ & $60^{\circ} \mathrm{C}$ & 0.995 & CK876943 $^{1}$ & New design \\
\hline & ATGAACCATTAGGCGGACAG & & & & & \\
\hline \multirow[t]{2}{*}{ PPAR $\alpha$} & TCCTGGTGGCCTACGGATC & $111 \mathrm{bp}$ & $60^{\circ} \mathrm{C}$ & 0.986 & DQ294237 ${ }^{1}$ & [67] \\
\hline & CGTTGAATTTCATGGCGAACT & & & & & \\
\hline \multirow[t]{2}{*}{ PPAR $\beta$} & GAGACGGTCAGGGAGCTCAC & $151 \mathrm{bp}$ & $60^{\circ} \mathrm{C}$ & 0.992 & AJ416953 ${ }^{1}$ & [67] \\
\hline & CCAGCAACCCGTCCTTGTT & & & & & \\
\hline \multirow[t]{2}{*}{ PPAR $\gamma$} & CATTGTCAGCCTGTCCAGAC & $144 \mathrm{bp}$ & $60^{\circ} \mathrm{C}$ & 0.999 & AJ416951 ${ }^{1}$ & [67] \\
\hline & TTGCAGCCCTCACAGACATG & & & & & \\
\hline \multirow[t]{2}{*}{ SREBP-1 } & GCCATGCGCAGGTTGTTTCTTCA & $151 \mathrm{bp}$ & $63^{\circ} \mathrm{C}$ & 0.942 & TC148424 ${ }^{2}$ & [20] \\
\hline & TCTGGCCAGGACGCATCTCACACT & & & & & \\
\hline \multirow[t]{2}{*}{ GST } & ATITGGGACGGGCTGACA & $81 \mathrm{bp}$ & $60^{\circ} \mathrm{C}$ & 0.989 & GE619558 ${ }^{1}$ & {$[68]$} \\
\hline & CCTGGTGCTCTGCTCCAGTT & & & & & \\
\hline \multirow[t]{2}{*}{ HOX } & GTCAACGCATCACCCTTCTT & $206 \mathrm{bp}$ & $60^{\circ} \mathrm{C}$ & 0.997 & BT046987 ${ }^{1}$ & New design \\
\hline & ATGGGGTCCTTCATCCTCTT & & & & & \\
\hline \multirow[t]{2}{*}{ GFPT1 } & GTGGTTTGGCAGACCTCCTA & $177 \mathrm{bp}$ & $60^{\circ} \mathrm{C}$ & 0.999 & NM_001140266 ${ }^{1}$ & New design \\
\hline & TGTACGGTGCCATCTTTCAA & & & & & \\
\hline \multirow[t]{2}{*}{ ApoB } & AGCCTTCGATGCTGTCGGCCA & $153 \mathrm{bp}$ & $60^{\circ} \mathrm{C}$ & 1.000 & TC79364 ${ }^{2}$ & {$[12]$} \\
\hline & AGGAGCACAGGCAGGGTGGTT & & & & & \\
\hline \multirow[t]{2}{*}{ EL } & CCGGTGCTGCTGGAGGAAGC & $378 \mathrm{bp}$ & $60^{\circ} \mathrm{C}$ & 0.962 & NM_001140535 ${ }^{1}$ & {$[12]$} \\
\hline & CGACATGCAGGTCATCGGT & & & & & \\
\hline \multirow[t]{2}{*}{ LPP2 } & TCCGGAAGAACTCGCAATAC & $174 \mathrm{bp}$ & $60^{\circ} \mathrm{C}$ & 0.949 & NM_001140716 ${ }^{1}$ & New design \\
\hline & ACATCACGTCCACCAAGACA & & & & & \\
\hline \multirow[t]{2}{*}{ AGPAT } & GAGAGCCAGAGGTTGAGGTG & $245 \mathrm{bp}$ & $60^{\circ} \mathrm{C}$ & 0.941 & NM_001141753 ${ }^{1}$ & New design \\
\hline & CAGAGTGAAGGCGATGTGAA & & & & & \\
\hline \multicolumn{7}{|l|}{ Reference genes: } \\
\hline \multirow[t]{2}{*}{ elf- $1 \alpha$} & CTGCCCCTCCAGGACGTTTACAA & $175 \mathrm{bp}$ & $60^{\circ} \mathrm{C}$ & 0.986 & AF321836 ${ }^{1}$ & {$[15]$} \\
\hline & CACCGGGCATAGCCGATTCC & & & & & \\
\hline \multirow[t]{2}{*}{$\beta$-actin } & ACATCAAGGAGAAGCTGTGC & $141 \mathrm{bp}$ & $56^{\circ} \mathrm{C}$ & 0.968 & AF012125 ${ }^{1}$ & {$[15]$} \\
\hline & GACAACGGAACCTCTCGTTA & & & & & \\
\hline \multirow[t]{2}{*}{ Cofilin-2 } & AGCCTATGACCAACCCACTG & $224 \mathrm{bp}$ & $60^{\circ} \mathrm{C}$ & 0.999 & TC63899 ${ }^{2}$ & {$[15]$} \\
\hline & TGTTCACAGCTCGTTTACCG & & & & & \\
\hline
\end{tabular}

${ }^{1}$ GenBank (http://www.ncbi.nlm.nih.gov/)

${ }^{2}$ Atlantic salmon Gene Index (http://compbio.dfci.harvard.edu/tgi/)

\section{Lipid extraction and fatty acid analyses}

Total lipids from six fish per treatment were extracted and determined gravimetrically from 1-2 g of liver by Ultra Turrax homogenisation in 20 volumes of chloroform/ methanol (2:1 v/v) [63]. Fatty acid methyl esters (FAME) were prepared by acid-catalysed transesterification of total lipids [64]. Following purification, FAME were separated and quantified by gas-liquid chromatography using a Thermo Fisher Trace GC 2000 (Thermo Fisher, Hemel Hempstead, UK) equipped with a fused silica capillary column (ZB wax, $30 \mathrm{~m} \times 0.32 \mathrm{mmi}$.d.; Phenomenex, Macclesfield, UK) with hydrogen as carrier gas and using 
on-column injection. The temperature gradient was from 50 to $150^{\circ} \mathrm{C}$ at $40^{\circ} \mathrm{C} / \mathrm{min}$ and then to $195^{\circ} \mathrm{C}$ at $1.5^{\circ} \mathrm{C} / \mathrm{min}$ and finally to $220^{\circ} \mathrm{C}$ at $2^{\circ} \mathrm{C} / \mathrm{min}$. Individual methyl esters were identified by comparison with known standards. Data were collected and processed using the Chromcard for Windows (version 2.00) computer package (Thermoquest Italia S.p.A., Milan, Italy).

\section{Statistical analysis}

Microarray hybridisation data were analysed in GeneSpring GX version 10.0.2 (Agilent Technologies) by twoway ANOVA, which examined the explanatory power of the variables 'diet' and 'genotype' (diet×genotype interaction presented in [12]), followed by Gene Ontology (GO) enrichment analysis, at a significance level of 0.05 . No multiple test correction was employed as previous analyses, confirmed by RT-qPCR, indicate that such corrections are over-conservative for this type of data [14]. Gene expression results assessed by RT-qPCR were analysed by the $\Delta \Delta \mathrm{Ct}$ method using the relative expression software tool (REST 2008, http://www.gene-quantification.info/), employing a pair wise fixed reallocation randomisation test (10,000 randomisations) with efficiency correction [65], to determine the statistical significance of expression ratios between two treatments. Finally, significant differences in liver fatty acid composition were determined by means of two-way ANOVA, at a significance level of $\mathrm{p}<$ 0.05, using the Graphpad Prism ${ }^{\mathrm{TM}}$ (version 4.0) statistical package (Graphpad Software, San Diego, CA).

\section{Acknowledgements \\ This study was funded by the EU FP6 IP "AQUAMAX" (Sustainable Aquafeeds to Maximise the Health Benefits of Farmed Fish for Consumers; 016249-2). SM was supported by a Marie Curie Intra European Fellowship (FP7-PEOPLE- 2007-2-1-IEF, Proposal N²19667) and JP by a Royal Thai Government Scholarship. The authors would like to acknowledge Landcatch Ltd for provision of the Lean and Fat smolts and to thank the staff of Marine Harvest Ltd, Ardnish FTU, for their assistance with fish husbandry and sample collection. Technical assistance from Jacquie Ireland in microarray hybridizations is deeply appreciated.}

\section{Author details \\ ${ }^{1}$ Institute of Aquaculture, University of Stirling, Stirling FK9 4LA, UK. ${ }^{2}$ Landcatch Natural Selection Ltd, The e-Centre, Cooperage Way, Alloa, FK10 3LP, UK. \\ Authors' contributions \\ SM and JP performed laboratory analyses and data analysis; DRG was responsible for family selection; JBT and JEB supported the microarray analysis; SM wrote the first draft of the manuscript, followed by contributions from remaining authors; SM, JGB and DRT planned and coordinated the research; DRG, JGB and DRT were project leaders. All authors read and approved the final manuscript.}

\section{Competing interests}

The authors declare that they have no competing interests.

Received: 22 March 2011 Accepted: 20 May 2011

Published: 20 May 2011

\section{References}

1. Calder PC, Yaqoob P: Omega-3 polyunsaturated fatty acids and human health outcomes. Biofactors 2009, 35:266-272.

2. FAO: The State of World Fisheries and Aquaculture 2008 Rome: Food and Agriculture Organization of the United Nations; 2009.

3. Tacon AGJ, Metian M: Global overview on the use of fish meal and fish oil in industrially compounded aquafeeds: Trends and future prospects. Aquaculture 2008, 285:146-158.

4. Rosenlund G, Corraze G, Izquierdo M, Torstensen BE: The effects of fish oil replacement on nutritional and organoleptic qualities of farmed fish. In Fish Oil Replacement and Alternative Lipid Sources in Aquaculture Feeds. Edited by: Turchini GM, Ng WK, Tocher DR. Boca Raton: CRC Press; 2010:487-522.

5. Gjedrem T, Baranski M: In Selective Breeding in Aquaculture: an Introduction Volume 10. London: Springer Science + Business Media B.V; 2009, Series: Reviews: Methods and Technologies in Fish Biology and Fisheries.

6. Leaver MJ, Taggart JB, Villeneuve L, Bron JE, Guy DR, Bishop SC, Houston RD, Matika O, Tocher DR: Heritability and mechanisms of n-3 long chain polyunsaturated fatty acid deposition in the flesh of Atlantic salmon. Comp Biochem Physiol Part D Genomics Proteomics 2011, 6:62-69.

7. Kolditz Cl, Paboeuf G, Borthaire M, Esquerré D, SanCristobal M, Lefèvre F, Médale F: Changes induced by dietary energy intake and divergent selection for muscle fat content in rainbow trout (Oncorhynchus mykiss), assessed by transcriptome and proteome analysis of the liver. BMC Genomics 2008, 9:506.

8. Kolditz C, Borthaire M, Richard N, Corraze G, Panserat S, Vachot C, Lefèvre F, Médale F: Liver and muscle metabolic changes induced by dietary energy content and genetic selection in rainbow trout (Oncorhynchus mykiss). Am J Physiol Regul Integr Comp Physiol 2008, 294:R1154-1164.

9. Jordal AE, Torstensen BE, Tsoi S, Tocher DR, Lall SP, Douglas SE: Dietary rapeseed oil affects the expression of genes involved in hepatic lipid metabolism in Atlantic salmon (Salmo salar L.). J Nutr 2005, 135:2355-2361.

10. Taggart JB, Bron JE, Martin SAM, Seear PJ, Høyheim B, Talbot R, Carmichael SN, Villeneuve LAN, Sweeney GE, Houlihan DF, Secombes CJ, Tocher DR, Teale AJ: A description of the origins, designs and performance of the TRAITS-SGP Atlantic salmon Salmo salar L. CDNA microarray. J Fish Biol 2008, 72:2071-2094.

11. Panserat S, Hortopan GA, Plagnes-Juan E, Kolditz C, Lansard M, SkibaCassy S, Esquerre D, Geurden I, Médale F, Kaushik S, Corraze G: Differential gene expression after total replacement of dietary fish meal and fish oil by plant products in rainbow trout (Oncorhynchus mykiss) liver. Aquaculture 2009, 294:123-131.

12. Morais S, Pratoomyot J, Torstensen BE, Taggart JB, Guy DR, Bell JG, Tocher DR: Diet $\times$ genotype interactions in hepatic cholesterol and lipoprotein metabolism in Atlantic salmon (Salmo salar) in response to replacement of dietary fish oil with vegetable oil. Br J Nutr

13. Allendorf FW, Thorgaard GH: Tetraploidy and the evolution of salmonid fishes. In Evolutionary Genetics of Fishes. Edited by: Turner BJ. New York: Plenum Press; 1984:55-93.

14. Leaver MJ, Villeneuve LA, Obach A, Jensen L, Bron JE, Tocher DR, Taggart JB: Functional genomics reveals increases in cholesterol biosynthetic genes and highly unsaturated fatty acid biosynthesis after dietary substitution of fish oil with vegetable oils in Atlantic salmon (Salmo salar). BMC Genomics 2008, 9:299.

15. Morais S, Monroig O, Zheng X, Leaver MJ, Tocher DR: Highly unsaturated fatty acid synthesis in Atlantic salmon: characterization of ELOVL5- and ELOVL2-like elongases. Mar Biotechnol 2009, 1:627-639.

16. Zheng X, Tocher DR, Dickson CA, Bell JG, Teale AJ: Effects of diets containing vegetable oil on expression of genes involved in highly unsaturated fatty acid biosynthesis in liver of Atlantic salmon (Salmo salar). Aquaculture 2004, 236:467-483.

17. Zheng X, Torstensen BE, Tocher DR, Dick JR, Henderson RJ, Bell JG: Environmental and dietary influences on highly unsaturated fatty acid biosynthesis and expression of fatty acyl desaturase and elongase genes in liver of Atlantic salmon (Salmo salar). Biochim Biophys Acta 2005, 1734:13-24.

18. Davidson $\mathrm{MH}$ : Mechanisms for the hypotriglyceridemic effect of marine omega-3 fatty acids. Am J Cardiol 2006, 98:27i-33i. 
19. Kim H, Choi S, Lee HJ, Lee JH, Choi H: Suppression of fatty acid synthase by dietary polyunsaturated fatty acids is mediated by fat itself, not by peroxidative mechanism. J Biochem Mol Biol 2003, 36:258-264.

20. Alvarez MJ, Díez A, López-Bote C, Gallego M, Bautista JM: Short-term modulation of lipogenesis by macronutrients in rainbow trout (Oncorhynchus mykiss) hepatocytes. Br J Nutr 2000, 84:619-628.

21. Torstensen $B E$, Frøyland $L$, Lie $\varnothing$ : Replacing dietary fish oil with increasing levels of rapeseed oil and olive oil - effects on Atlantic salmon (Salmo salar L.) tissue and lipoprotein lipid composition and lipogenic enzyme activities. Aquacult Nutr 2004, 10:175-192.

22. Richard N, Kaushik S, Larroquet L, Panserat S, Corraze G: Replacing dietary fish oil by vegetable oils has little effect on lipogenesis, lipid transport and tissue lipid uptake in rainbow trout (Oncorhynchus mykiss). Br J Nutr 2006, 96:299-309.

23. Minghetti M, Leaver MJ, Tocher DR: Transcriptional control mechanisms of genes of lipid and fatty acid metabolism in the Atlantic salmon (Salmo salar L.) established cell line, SHK-1. Biochim Biophys Acta Molecular and Cell Biology of Lipids 2011, 1811:194-202.

24. Boukouvala E, Antonopoulou E, Favre-Krey L, Diez A, Bautista JM, Leaver MJ, Tocher DR, Krey G: Molecular characterization of three peroxisome proliferator-activated receptors from the sea bass (Dicentrarchus labrax). Lipids 2004, 39:1085-1092.

25. Leaver MJ, Boukouvala E, Antonopoulou E, Diez A, Favre-Krey L, Ezaz MT, Bautista JM, Tocher DR, Krey G: Three peroxisome proliferator-activated receptor isotypes from each of two species of marine fish. Endocrinology 2005, 146:3150-3162

26. Kondo H, Misaki R, Gelman L, Watabe S: Ligand-dependent transcriptional activities of four torafugu pufferfish Takifugu rubripes peroxisome proliferator-activated receptors. Gen Comp Endocrinol 2007, 154:120-127.

27. Kjær MA, Todorcević $M$, Torstensen BE, Vegusdal A, Ruyter B: Dietary $n-3$ HUFA affects mitochondrial fatty acid beta-oxidation capacity and susceptibility to oxidative stress in Atlantic salmon. Lipids 2008, 43:813-827.

28. Jordal A-EO, Lie $\varnothing$, Torstensen BE: Complete replacement of dietary fish oil with a vegetable oil blend affect liver lipid and plasma lipoproteins levels in Atlantic salmon (Salmo salar L.). Aquacult Nutr 2007, 13:114-130.

29. Jump DB, Clarke SD, Thelen A, Liimatta M, Ren B, Badin M: Dietary polyunsaturated fatty acid regulation of gene transcription. Prog Lipid Res 1996, 35:227-241.

30. Clarke SD: Polyunsaturated fatty acid regulation of gene transcription: a molecular mechanism to improve the metabolic syndrome. J Nutr 2001, 131:1129-1132

31. Nakamura MT, Nara TY: Gene regulation of mammalian desaturases. Biochem Soc Trans 2002, 30:1076-1079.

32. Wang Y, Botolin D, Christian B, Busik J, Xu J, Jump DB: Tissue-specific, nutritional, and developmental regulation of rat fatty acid elongases. $J$ Lipid Res 2005, 46:706-715.

33. Tang C, Cho HP, Nakamura MT, Clarke SD: Regulation of human $\Delta-6$ desaturase gene transcription: identification of a functional direct repeat-1 element. J Lipid Res 2003, 44:686-695.

34. Zheng X, Leaver MJ, Tocher DR: Long-chain polyunsaturated fatty acid synthesis in fish: Comparative analysis of Atlantic salmon (Salmo salar L.) and Atlantic cod (Gadus morhua L.) $\Delta 6$ fatty acyl desaturase gene promoters. Comp Biochem Physiol B Biochem Mol Biol 2009, 154:255-263.

35. Paine MJI, Scrutton NS, Munro AW, Gutierrez A, Roberts GCK, Wolf CR: Electron transfer partners of cytochrome P450. In Cytochrome P450: structure, mechanism and biochemistry.. 3 edition. Edited by: Ortiz de Montellano PR. NY: Kluwer Academic/Plenum Publishers; 2005:115-148.

36. Moon TW: Glucose intolerance in teleost fish: fact or fiction? Comp Biochem Physiol 2001, 129B:243-249.

37. Hemre Gl, Mommsen TP, Krogdahl $\AA$ : Carbohydrates in fish nutrition: effects on growth, glucose metabolism and hepatic enzymes. Aquac Nutr 2002, 8:175-194.

38. Menoyo D, Diez A, Lopez-Bote CJ, Casado S, Obach A, Bautista JM: Dietary fat type affects lipid metabolism in Atlantic salmon (Salmo salar L.) and differentially regulates glucose transporter GLUT4 expression in muscle. Aquaculture 2006, 261:294-304.

39. Sriram G, Rahib L, He JS, Campos AE, Parr LS, Liao JC, Dipple KM: Global metabolic effects of glycerol kinase overexpression in rat hepatoma cells. Mol Genet Metab 2008, 93:145-159.
40. McMahon RJ: Biotin in metabolism and molecular biology. Annu Rev Nutr 2002, 22:221-239.

41. Shepherd PR, Withers DJ, Siddle K: Phosphoinositide 3-kinase: the key switch mechanism in insulin signalling. Biochem J 1998, 333:471-490.

42. Delcommenne M, Tan C, Gray V, Rue L, Woodgett J, Dedhar S: Phosphoinositide-3-OH kinase-dependent regulation of glycogen synthase kinase 3 and protein kinase B/AKT by the integrin-linked kinase. Proc Natl Acad Sci USA 1998, 95:11211-11216.

43. Yost C, Farr GH, Pierce SB, Ferkey DM, Chen MM, Kimelman D: GBP, an inhibitor of GSK-3, is implicated in Xenopus development and oncogenesis. Cell 1998, 93:1031-1041.

44. Takahashi M, Tsuboyama-Kasaoka N, Nakatani T, Ishii M, Tsutsumi S, Aburatani $\mathrm{H}$, Ezaki O: Fish oil feeding alters liver gene expressions to defend against PPARa activation and ROS production. Am J Physiol Gastrointest Liver Physiol 2002, 282:G338-348.

45. Saera-Vila A, Benedito-Palos L, Sitjà-Bobadilla A, Nàcher-Mestre J, Serrano R Kaushik S, Pérez-Sánchez J: Assessment of the health and antioxidant trade-off of gilthead sea bream (Sparus aurata) fed alternative diets with low levels of contaminants. Aquaculture 2009, 296:87-95.

46. Finne EF, Olsvik PA, Berntssen MH, Hylland K, Tollefsen KE: The partial pressure of oxygen affects biomarkers of oxidative stress in cultured rainbow trout (Oncorhynchus mykiss) hepatocytes. Toxicol In Vitro 2008, 22:1657-1661.

47. Leaver MJ, George SG: A piscine glutathione S-transferase which efficiently conjugates the end-products of lipid peroxidation. Mar Environ Res 1998, 46:71-74.

48. Barnes CJ, Cameron IL, Puleo-Scheppke B, Lee M: Age alters expression and inducibility of heme oxygenase isozymes in mice. Age 1998, 21:123-128.

49. Wagener FA, Volk HD, Willis D, Abraham NG, Soares MP, Adema GJ, Figdor CG: Different faces of the heme-heme oxygenase system in inflammation. Pharmacol Rev 2003, 55:551-571.

50. Calder PC: $\mathrm{n}-3$ polyunsaturated fatty acids, inflammation, and inflammatory diseases. Am J Clin Nutr 2006, 83(6 Suppl):1505S-1519S,

51. Estensoro I, Benedito-Palos L, Palenzuela O, Kaushik S, Sitjà-Bobadilla $A$ Pérez-Sánchez J: The nutritional background of the host alters the disease course in a fish-myxosporean system. Vet Parasitol 2011, 175:141-150

52. Oxley A, Jolly C, Eide T, Jordal AE, Svardal A, Olsen RE: The combined impact of plant-derived dietary ingredients and acute stress on the intestinal arachidonic acid cascade in Atlantic salmon (Salmo salar). $\mathrm{Br} \mathrm{J}$ Nutr 2010, 103:851-861.

53. Boggs JM, Koo CH, Goetzl EJ: Down-regulation of receptor antigen in leukotriene B4-induced chemotactic deactivation of human polymorphonuclear leucocytes. Immunology 1991, 73:212-216.

54. Lawrence RH, Sorrell TC: Eicosapentaenoic acid modulates neutrophil leukotriene B4 receptor expression in cystic fibrosis. Clin Exp Immunol 1994, 98:12-16.

55. Valitutti S, Müller S, Salio M, Lanzavecchia A: Degradation of T cell

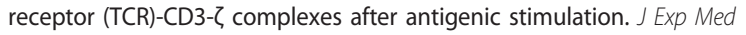
1997, 185:1859-1864.

56. Dircks L, Sul HS: Acyltransferases of de novo glycerophospholipid biosynthesis. Prog Lipid Res 1999, 38:461-479.

57. Jasinska R, Zhang QX, Pilquil C, Singh I, Xu J, Dewald J, Dillon DA Berthiaume LG, Carman GM, Waggoner DW, Brindley DN: Lipid phosphate phosphohydrolase-1 degrades exogenous glycerolipid and sphingolipid phosphate esters. Biochem J 1999, 340:677-686.

58. Tsai ML, Chen HY, Tseng MC, Chang RC: Cloning of peroxisome proliferators activated receptors in the cobia (Rachycentron canadum) and their expression at different life-cycle stages under cage aquaculture. Gene 2008, 425:69-78.

59. Collin A, Swennen Q, Skiba-Cassy S, Buyse J, Chartrin P, Le Bihan-Duval E, Crochet S, Duclos MJ, Joubert R, Decuypere E, Tesseraud S: Regulation of fatty acid oxidation in chicken (Gallus gallus): interactions between genotype and diet composition. Comp Biochem Physiol B Biochem Mol Biol 2009, 153:171-177

60. Bell JG, Pratoomyot J, Strachan F, Henderson RJ, Fontanillas R, Hebard A, Guy DR, Hunter D, Tocher DR: Growth, flesh adiposity and fatty acid composition of Atlantic salmon (Salmo salar) families with contrasting flesh adiposity: Effects of replacement of dietary fish oil with vegetable oils. Aquaculture 2010, 306:225-232. 
61. National Research Council (NRC): Nutrient Requirements of Fish Washington D.C.: National Academy Press; 1993.

62. Brazma A, Hingamp P, Quackenbush J, Sherlock G, Spellman P, Stoeckert C, Aach J, Ansorge W, Ball CA, Causton HC, Gaasterland T, Glenisson P, Holstege FC, Kim IF, Markowitz V, Matese JC, Parkinson H, Robinson A, Sarkans U, Schulze-Kremer S, Stewart J, Taylor R, Vilo J, Vingron M: Minimum information about a microarray experiment (MIAME)-toward standards for microarray data. Nat Genet 2001, 29:365-371.

63. Folch J, Lees M, Sloane-Stanley GH: A simple method for the isolation and purification of total lipides from animal tissues. J Biol Chem 1957, 226:497-509.

64. Christie WW: Lipid analysis Bridgewater: The Oily Press; 2003.

65. Pfaffl MW, Horgan GW, Dempfle L: Relative expression software tool (REST) for group-wise comparison and statistical analysis of relative expression results in real-time PCR. Nucleic Acids Res 2002, 30:e36.

66. Zheng X, Tocher DR, Dickson CA, Bell JG, Teale AJ: Highly unsaturated fatty acid synthesis in vertebrates: new insights with the cloning and characterization of a $\Delta 6$ desaturase of Atlantic salmon. Lipids 2005, 40:13-24.

67. Kleveland EJ, Ruyter B, Vegusdal A, Sundvold H, Berge RK, Gjøen T: Effects of 3-thia fatty acids on expression of some lipid related genes in Atlantic salmon (Salmo salar L.). Comp Biochem Physiol B Biochem Mol Biol 2006, 145:239-248.

68. Olsvik PA, Torstensen BE, Berntssen MHG: Effects of complete replacement of fish oil with plant oil on gastrointestinal cell death, proliferation and transcription of eight genes' encoding proteins responding to cellular stress in Atlantic salmon Salmo salar L. J Fish Biol 2007, 71:550-568.

doi:10.1186/1471-2164-12-255

Cite this article as: Morais et al.: Genotype-specific responses in Atlantic salmon (Salmo salar) subject to dietary fish oil replacement by vegetable oil: a liver transcriptomic analysis. BMC Genomics 2011 12:255.

\section{Submit your next manuscript to BioMed Central and take full advantage of:}

- Convenient online submission

- Thorough peer review

- No space constraints or color figure charges

- Immediate publication on acceptance

- Inclusion in PubMed, CAS, Scopus and Google Scholar

- Research which is freely available for redistribution

Submit your manuscript at www.biomedcentral.com/submit 